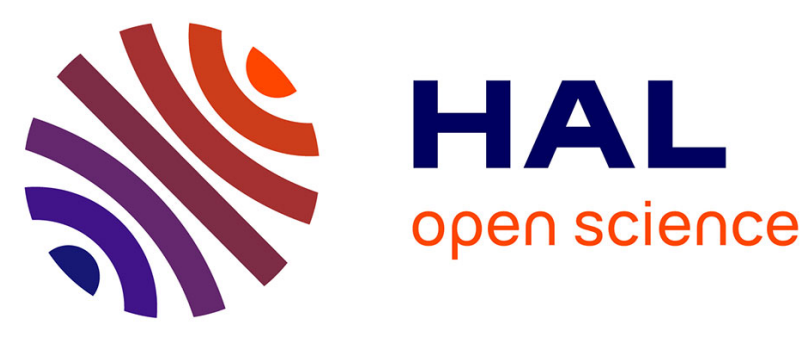

\title{
Mechanistic diversity in acetophenone transfer hydrogenation catalyzed by ruthenium iminophosphonamide complexes
}

Alexander Kalsin, Tatyana Peganova, Iana Sinopalnikova, Ivan Fedyanin, Natalia V Belkova, Éric Deydier, Rinaldo Poli

\section{To cite this version:}

Alexander Kalsin, Tatyana Peganova, Iana Sinopalnikova, Ivan Fedyanin, Natalia V Belkova, et al.. Mechanistic diversity in acetophenone transfer hydrogenation catalyzed by ruthenium iminophosphonamide complexes. Dalton Transactions, 2020, 49 (5), pp.1473-1484. 10.1039/c9dt04532e . hal02563774

\section{HAL Id: hal-02563774 \\ https://hal.science/hal-02563774}

Submitted on 1 Mar 2021

HAL is a multi-disciplinary open access archive for the deposit and dissemination of scientific research documents, whether they are published or not. The documents may come from teaching and research institutions in France or abroad, or from public or private research centers.
L'archive ouverte pluridisciplinaire HAL, est destinée au dépôt et à la diffusion de documents scientifiques de niveau recherche, publiés ou non, émanant des établissements d'enseignement et de recherche français ou étrangers, des laboratoires publics ou privés. 


\section{Mechanistic diversity in acetophenone transfer hydrogenation catalyzed by ruthenium iminophosphonamide complexes}

Received 00th January 20xx, Accepted 00th January 20xx DOI: $10.1039 / x 0 x \times 00000 x$

\author{
Alexander M. Kalsin, ${ }^{* a}$ Tatyana A. Peganova, ${ }^{a}$ Iana S. Sinopalnikova, ${ }^{\mathrm{a}, \mathrm{b}}$ Ivan V. Fedyanin, ${ }^{\mathrm{a}}$ Natalia V. \\ Belkova, ${ }^{a}$ Eric Deydier, ${ }^{\text {b }}$ Rinaldo Poli ${ }^{\mathrm{b}, \mathrm{c*}}$
}

\section{Introduction}

With the discovery of metal-ligand bifunctional catalysts, ${ }^{1}$ transfer hydrogenation of ketones has become a highly efficient method for the synthesis of secondary (chiral) alcohols. ${ }^{2,3}$ In this regard, the Noyori-Ikariya catalysts [(Arene)RuCl(Tsdpen) $]^{4}$ and structurally similar complexes ${ }^{5-11}$ have drawn much attention and the effect of structural changes on the activity and on the catalytic mechanism have been extensively studied both experimentally and theoretically. ${ }^{12-20}$ The "accepted" mechanism for bifunctional catalytic hydrogenation by the Noyori-lkariya catalysts has been postulated to proceed as a concerted outer-sphere proton/hydride transfer from the metal centre to the substrate carbonylic carbon via a highly-ordered pericyclic transition state involving the ligand $\mathrm{NH}$ group, ${ }^{12}$ the formation of which is responsible for high activities and chemo/enantioselectivities. However, the degree of synchronism of the hydride and proton transfer has been further discussed to suggest alternatively the existence of a spectrum of possible reaction pathways ranging from concerted to stepwise proton/hydride transfer, with the proton either transiting through a ligand or being directly transferred from $\mathrm{H}_{2}$ to the alkoxide product. ${ }^{21-24}$ In most cases the presence of an $\mathrm{NH}$

\footnotetext{
a.A.N. Nesmeyanov Institute of Organoelement Compounds, Russian Academy of Sciences, 28 Vavilov str., 119991 Moscow, Russia.

b. CNRS, Laboratoire de Chimie de Coordination, Université de Toulouse, UPS, INPT, 205 Route de Narbonne, 31077 Toulouse Cedex 4, France. Email: rinaldo.poli@lcctoulouse.fr.

c. Institut Universitaire de France, 1, rue Descartes, 75231 Paris Cedex 05, France.
}

Electronic Supplementary Information (ESI) available: [details of any supplementary information available should be included here]. See DOI: 10.1039/x0xx00000x function is a crucial prerequisite rendering the catalyst highly efficient.

Recently we have demonstrated for the first time that ruthenium iminophosphonamide [( $p$-Cymene) $\mathrm{RuCl}\left(\mathrm{Ph}_{2} \mathrm{P}(\mathrm{N}-p-\right.$ (ol) $)_{2}$ ] (1f) can catalyse transfer hydrogenation of acetophenone in isopropanol under basic conditions. ${ }^{25}$ In contrast to isoelectronic Noyori-lkariya catalysts, the NPN ligand in $\mathbf{1 f}$ is not deprotonatable and therefore no ligand assistance in the hydrogen transfer step is possible. We have proposed a catalytic cycle that involves an outer-sphere transfer of the hydridic atom from the in situ generated hydride complex $\left[(p\right.$-Cymene $\left.) \mathrm{RuH}\left(\mathrm{Ph}_{2} \mathrm{P}(\mathrm{N}-\mathrm{p} \text {-Tol })_{2}\right)\right](\mathbf{2 f})$ to the carbonyl atom via the zwitterionic intermediate $\left[\left(p\right.\right.$-Cymene) $\mathrm{Ru}^{+}(\mathrm{NPN})(\mathrm{H} \ldots \mathrm{C}(\mathrm{O}$ )MePh], while the proton is delivered by the alcohol solvent. This mechanistic proposition was supported by model experiments, kinetic studies and DFT calculations. Arene ruthenium iminophosphonamides are electron-rich complexes due to zwitterionic nature of the $\mathrm{R}_{2} \mathrm{P}^{+}\left(\mathrm{NR}^{\prime}\right)_{2}$ (NPN) ligand, which makes the $18 \overline{\mathrm{e}}$ [(Arene)Ru(NPN)X] complexes coordinatively labile and stabilizes their $16 \bar{e} \quad[(\text { Arene }) \mathrm{Ru}(\mathrm{NPN})]^{+} \mathrm{X}^{-}$ counterparts. ${ }^{26}$ The $18 \overline{\mathrm{e}}$ complexes with electron-donating $\mathrm{N}$ and $\mathrm{P}$-substituents are prone to dissociation and are susceptible to electrophilic attack of the basic $\mathrm{N}$-atoms. Therefore, such electron-donating $\mathrm{N}$ - and P-substituents may significantly change the propensity of the $\mathrm{N}$-atoms to protonation, which can ultimately realize the concerted proton/hydride transfer in catalytic reduction of ketones.

In this paper we report on the acetophenone transfer hydrogenation with isopropanol catalyzed by arene ruthenium iminophosphonamide complexes [(Arene)RuCl(NPN)] (1a-e, Chart 1 ) bearing various $\mathrm{N}$ - and P-substituents on the NPN ligand (A-E), including kinetic studies and DFT calculations in support of the catalytic mechanism. The exploration of a wider 

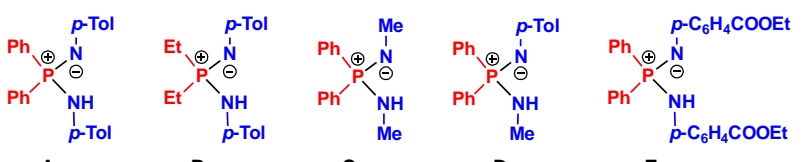

B

C

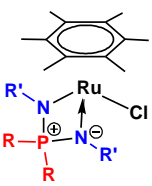

a, $\mathrm{R}=\mathrm{Ph}, \mathrm{R}^{\prime}=p-\mathrm{Tol}$

1b, $\mathrm{R}=\mathrm{Et}, \mathrm{R}^{\prime}=p-\mathrm{Tol}$

1c, $R=P h, R^{\prime}=M e$

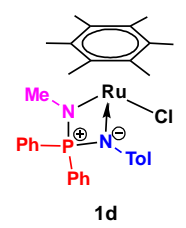

$1 d$

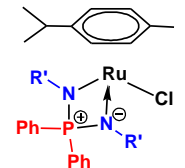

1e, $\mathrm{R}^{\prime}=p-\mathrm{C}_{6} \mathrm{H}_{4} \mathrm{CO}_{2} \mathrm{Et}$ 1f, $\mathrm{R}^{\prime}=p$-Tol
Chart 1. The list of NPN ligands and RuNPN complexes employed in this study

range of complexes differing by the nature of the arene, $\mathrm{N}$ and $P$ substituents, has revealed the presence of two alternative mechanisms, with the preferred pathway controlled by the NPN ligand basicity.

\section{Results and Discussion}

The synthesis and properties of the complexes $\mathbf{1 a - c}$ and $\mathbf{1 f}$ have been previously reported, ${ }^{26,27}$ while the new complexes $1 \mathbf{d}$ and 1e bearing the nonsymmetrical N-methyl- $N^{\prime}-p$-tolyl-substituted ligand $\mathbf{D}$ and the ligand $\mathbf{E}$ with electron-withdrawing $\mathrm{N}-\mathrm{Ar}^{*}$ ( $\mathrm{Ar}$ * $=p-\mathrm{C}_{6} \mathrm{H}_{4} \mathrm{CO}_{2} \mathrm{Et}$ ) groups, respectively, are described here for the first time.

\section{(a) Synthesis of $\left[\left(\mathrm{C}_{6} \mathrm{Me}_{6}\right) \mathrm{Ru}\left\{\mathrm{Ph}_{2} \mathrm{P}(\mathrm{N}-\mathrm{p}-\mathrm{Tol})(\mathrm{NMe})\right\} \mathrm{Cl}\right]$ (1d) and [(p- Cymene)Ru $\left.\left\{\mathrm{Ph}_{2} \mathrm{P}\left(\mathrm{N}-\mathrm{Ar}{ }^{*}\right)_{2}\right\} \mathrm{Cl}\right]$ (1e).}

The unknown iminophosphonamine $\mathbf{E}$ was quantitatively obtained from the corresponding diaminophosphonium salt $\left[\mathrm{Ph}_{2} \mathrm{P}\left(\mathrm{NHAr}^{*}\right)_{2}\right] \mathrm{Br}^{28}$ by deprotonation with diethylamine. It was fully characterized by NMR spectroscopy and elemental analysis.

The new arene ruthenium complexes $\mathbf{1 d}$ and $\mathbf{1 e}$ were synthesized according to the previously published procedure, ${ }^{27}$ i.e. by reacting $\left[(\text { Arene }) \mathrm{RuCl}_{2}\right]_{2}$ with the known iminophosphonamine $\mathbf{D}^{29}$ or the new proligand $\mathbf{E}$, respectively, deprotonated with 1 equiv. NaHMDS in benzene (Scheme 1).

The isolated products were fully characterized by multinuclear NMR spectroscopy and elemental analysis, and<smiles>CN[PH]([O-])(c1ccccc1)c1ccc(C)cc1</smiles>

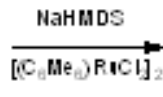

D

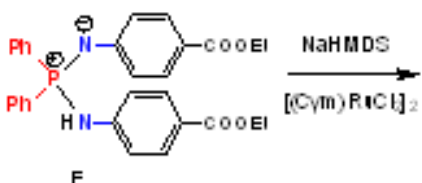

E
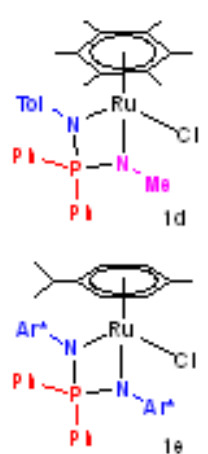

Scheme 1. Synthesis of complexes $1 \mathrm{~d}$ and $1 \mathrm{e}$

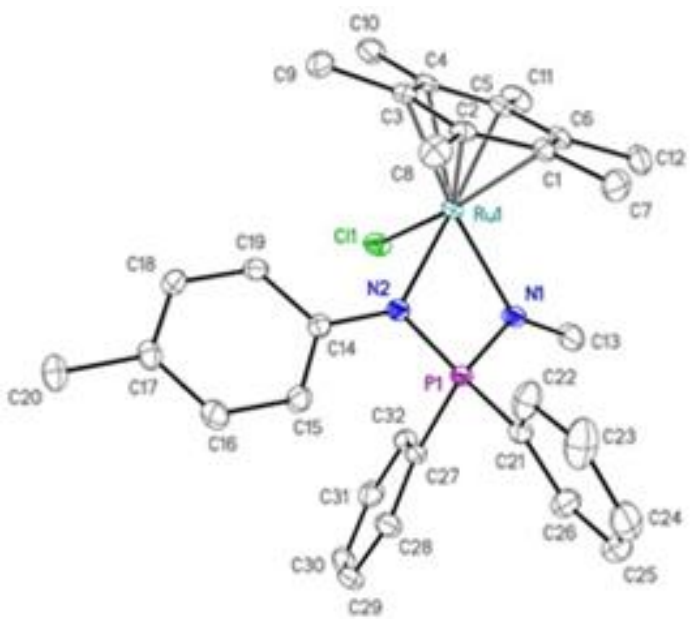

Figure 1. ORTEP diagram of $\mathbf{1 d}$. Ellipsoids are shown at the $50 \%$ probability level; hydrogen atoms are omitted for clarity. Selected bond lengths $(\AA)$ and angles $\left({ }^{\circ}\right)$ : Ru‥Arene(centroid) 1.673, Ru-Cl 2.4276(5), Ru-N1 2.1373(14), Ru-N2 2.1736(14), N1-Ru-N2 68.26(5), Ru-N1-P-N2 179.48(9), $\Sigma(N 1) 359.0, \Sigma(N 2) 358.9$.

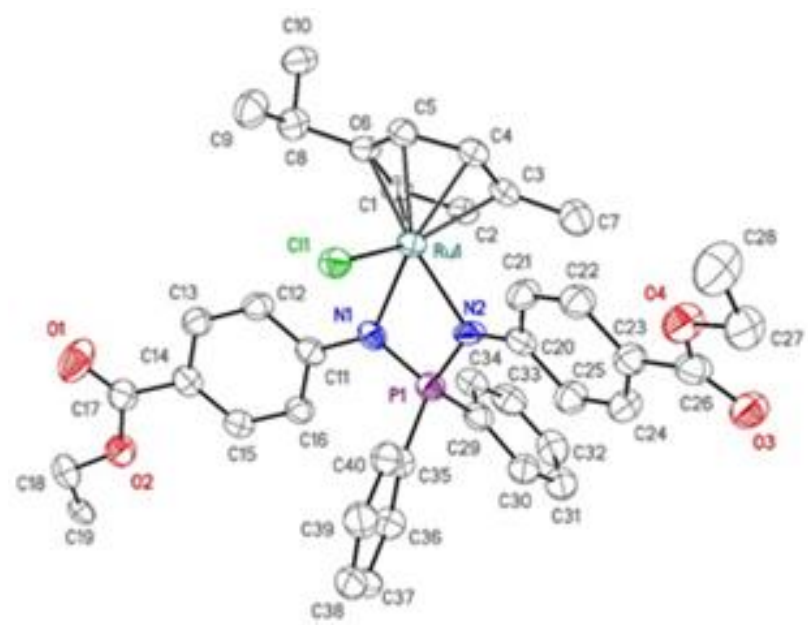

Figure 2. ORTEP diagram of 1e. Ellipsoids are shown at 50\% probability, hydrogen atoms are omitted for clarity. Only one fragment of the disordered cymene and OEt fragments is shown. Selected bond lengths $(\AA)$ and angles $\left({ }^{\circ}\right)$ :

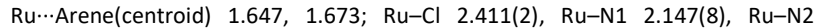

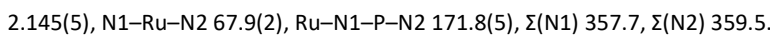

their molecular structures were confirmed by single crystal Xray diffraction studies (Figures 1 and 2, Table S1 in ESI).

Complexes 1d and 1e exhibit a three-legged piano stool geometry with a pseudo octahedral configuration of the ligands around the ruthenium atom. Their structural parameters are similar to those of $\mathrm{C}_{6} \mathrm{Me}_{6}$ and $p$-cymene analogues $\mathbf{1 a - c}$ and $\mathbf{1 f}$, respectively, for which a detailed structural analysis has previously been reported. 26,27 Expectedly, the Ru-N and $\mathrm{Ru}-\mathrm{Cl}$ distances are slightly shorter for complex 1e (2.146(8) $\AA$ and 2.411(2) $\AA$, respectively) than for $1 \mathrm{~d}$ (2.1555(14) $\AA$ and $2.4276(5) \AA$, respectively), because of the effect of the $p$ cymene ligand and the electron-withdrawing $\mathrm{N}$-aryl groups of the iminophosphonamide moiety. As a result of the delocalization of the unpaired electron density of the nitrogen atoms on the $\mathrm{N}$-aryl substituents, the pyramidalisation of the 

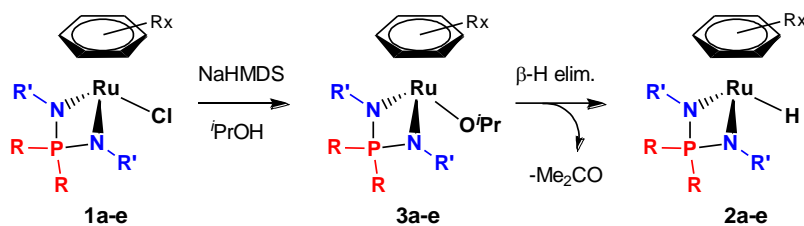

Scheme 2. General scheme for generation of hydride complexes $\mathbf{2 a - e}$

nitrogen atoms for $\mathbf{1 d}, \mathbf{e}$ is small, $\Sigma(\mathrm{N})=357.7-359.5^{\circ}$, similarly to complexes $\mathbf{1 a}, \mathbf{b}, \mathbf{f}$. The $\operatorname{Ru}(1) \mathrm{N}(1) \mathrm{P}(1) \mathrm{N}(2)$ metallacycle is slightly bent by $0.5^{\circ}(\mathbf{1 d})$ and $8.2^{\circ}(\mathbf{1 e})$ from planarity. The $p$ cymene ring and one of the OEt fragments in 1e are disordered among two positions with almost equal occupancies for each component (refined as 0.49:0.51).

Analogously to $\mathbf{1 b}$ and $\mathbf{1 c},{ }^{26}$ the $\mathrm{Ph}$ groups at the phosphorus atom in the complex $1 \mathbf{d}$ experience degenerative exchange due to facile chloride dissociation with an exchange rate constant $k_{\text {ex }}$ $=3.4 \mathrm{~s}^{-1}$ and a Gibbs activation energy $\Delta G_{\mathrm{ex}}{ }^{\neq}=16.5 \mathrm{kcal} / \mathrm{mol}$, which is $2.0 \mathrm{kcal} / \mathrm{mol}$ higher than that for 1c having two donating N-Me substituents (Figure S1, Table S2). The same exchange for $\mathbf{1 e}$ is expected to be even slower than for $\mathbf{1 f}$, for which the $\Delta G_{\mathrm{ex}}{ }^{\neq}$in benzene was estimated to be greater than $18.5 \mathrm{kcal} / \mathrm{mol} .{ }^{26}$ Indeed, no exchange for $1 \mathrm{e}$ was detected in $\mathrm{C}_{6} \mathrm{D}_{6}$, while even in the relatively polar $\mathrm{CDCl}_{3}$ the ortho- $\mathrm{H}$ of the two different phenyl groups are observed separately (Figure S2), indicating a very slow exchange.

\section{(b) Generation and stability of [(Arene) $\mathrm{Ru}(\mathrm{NPN}) \mathrm{H}]$ species.}

We have recently described the generation of a hydride complex $\left[\left(p\right.\right.$-Cymene)RuH(NPN)] (2f, NPN $\left.=\mathrm{Ph}_{2} \mathrm{P}(\mathrm{N}-p \text {-Tol })_{2}\right)$ from the corresponding chloride $\mathbf{1 f}$ and sodium isopropoxide via $6-\mathrm{H}$ elimination in the isopropoxide intermediate $[(p-$ Cymene)Ru(O'Pr)(NPN)] (3f). ${ }^{25}$ Here we show that this procedure is operational for the generation of a wider array of ruthenium hydrides [(Arene)RuH(NPN)] (2a-e) from the corresponding chloride complexes 1a-e, although the stability of the products is very different.

The chloride complexes 1a-e were treated with 1-1.5 equiv. of $\mathrm{NaHMDS}$ in $\mathrm{C}_{6} \mathrm{D}_{6} /{ } \mathrm{PrOH}=500 / 10-40 \mu \mathrm{L}$ at room temperature and the generation of the corresponding hydride complexes $2 \mathrm{a}$ e (Scheme 2) was monitored by ${ }^{31} \mathrm{P}$ and ${ }^{1} \mathrm{H}$ NMR spectroscopy. The formation of $\left[\left(\mathrm{C}_{6} \mathrm{Me}_{6}\right) \mathrm{RuH}\left(\mathrm{Ph}_{2} \mathrm{P}(\mathrm{N}-p \text {-Tol })_{2}\right)\right]$ (2a) proceeds via the observable isopropoxide intermediate $\left[\left(\mathrm{C}_{6} \mathrm{Me}_{6}\right) \mathrm{Ru}(\mathrm{O} \mathrm{PPr})\right.$ $\left.\left(\mathrm{Ph}{ }_{2} \mathrm{P}(\mathrm{N}-\mathrm{p}-\mathrm{Tol})_{2}\right)\right](3 \mathrm{a})$, which predominates in the mixture during the first $15 \mathrm{~min}$ of the reaction, and is complete within 2 hrs (Figure 3). Complex 3a was identified by the characteristic septet of the methyne group of the isopropoxy ligand in the initial ${ }^{1} \mathrm{H}$ NMR spectrum (Figure $\mathrm{S} 3$ ).

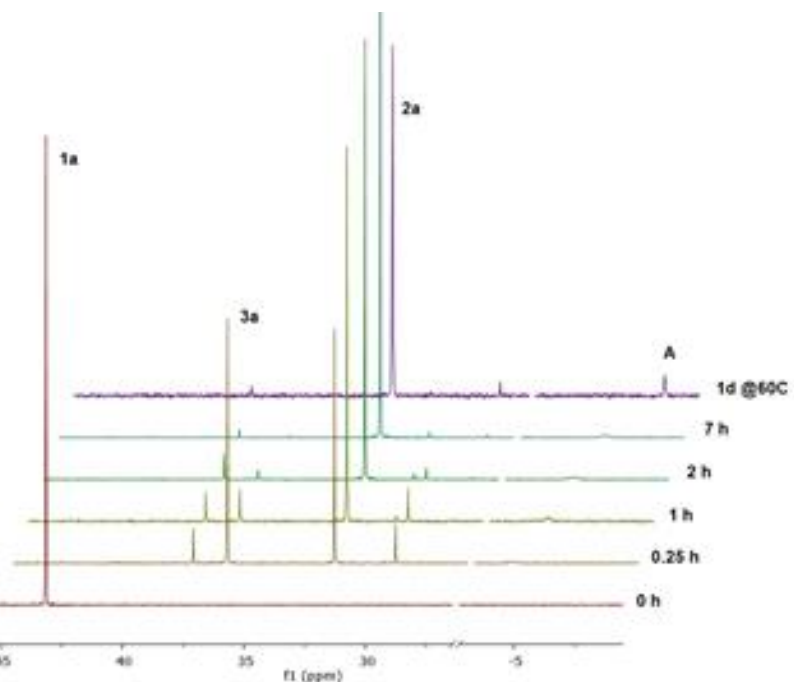

Figure 3. ${ }^{31} \mathrm{P}\left\{{ }^{1} \mathrm{H}\right\}$ NMR monitoring of the reaction of 1a with NaHMDS/PrOH in $\mathrm{C}_{6} \mathrm{D}_{6}$. Conditions: $\mathrm{C}_{6} \mathrm{D}_{6}(0.5 \mathrm{~mL}), i \mathrm{PrOH}(10 \mu \mathrm{L}), 1 \mathrm{a}(0.02 \mathrm{mmol})$, NaHDMS $(2 \mathrm{M}$ in $\mathrm{THF}, 15 \mu \mathrm{L}), \mathbf{1 a} / \mathrm{iPrOH}=1 / 8, \mathrm{HMDS} / \mathbf{1 a}=1.5$.

Unlike the $p$-cymene analogue $\mathbf{2} \mathbf{f}$, the hydride $\mathbf{2 a}$ is stable for days. It does not decompose or undergo rearrangement into an isomeric cyclohexadienyl complex, even upon prolonged heating at $60^{\circ} \mathrm{C}$ (though traces of the iminophosphonamine $\mathbf{A}$ due to NPN ligand protonolysis were visible after 1 day), apparently due to steric bulk of the $\mathrm{C}_{6} \mathrm{Me}_{6}$ ligand. Complex $2 \mathrm{a}$ was isolated from the reaction mixture and characterized by ${ }^{1} \mathrm{H}$, ${ }^{31} \mathrm{P}$ and ${ }^{13} \mathrm{C}$ NMR spectroscopy (Figures $\mathrm{S} 4$ ). In the ${ }^{1 \mathrm{H}} \mathrm{NMR}$ spectrum, the RuH signal is observed at $\delta-3.25$ in pure benzene$d_{6}$. Despite many attempts, we were not able to obtain suitable crystals for an X-ray analysis.

Replacing the phenyl P-substituents with more electrondonating ethyl groups in $\mathbf{1 b}$ does not affect the hydride $\mathbf{2} \mathbf{b}$ generation time from the corresponding isopropoxide $\mathbf{3 b}$, while it causes side reactions to occur (Figure S5). The initially observed resonance at $\delta 64.5$ in ${ }^{31} \mathrm{P}$ NMR (Figure S5(b)) and the septet of $\mathrm{CHMe}_{2}$ at $\delta 4.59$ in ${ }^{1} \mathrm{H}$ NMR (Figure $\mathrm{S} 6$ ) were assigned to $3 \mathbf{b}$, while the ${ }^{31} \mathrm{P}$ NMR singlet at $\delta 63.3$ and the ${ }^{1} \mathrm{H}$ NMR resonance at $\delta-4.18$ (Figures 57 ) were attributed to $\mathbf{2 b}$. Apart from few minor impurities, this reaction also yields $\mathbf{4} \mathbf{b}$, characterized by a ${ }^{31} \mathrm{P}$ NMR resonance at $\delta 39.8$ and by a doublet of septets at $\delta 4.53\left({ }^{3} J_{\mathrm{PH}}=9.2 \mathrm{~Hz},{ }^{3} J_{\mathrm{CH}}=6.0 \mathrm{~Hz}\right)$ in the ${ }^{1} \mathrm{H}$ NMR spectrum, which appears to correspond to the $\mathrm{N}-i \mathrm{Pr}$ substituted aminophosphine oxide $\mathrm{Et}_{2} \mathrm{P}(\mathrm{O})-\mathrm{N}$ ('Pr)Tol (Figure $\mathrm{S} 7$, insert). The amount of $\mathbf{4 b}$ increases simultaneously with the generation of $\mathbf{2} \mathbf{b}$, suggesting that it forms by the competing

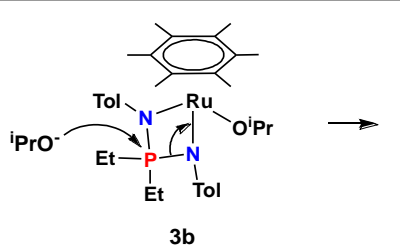

3b

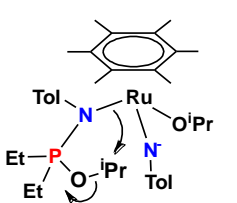

Et ${ }^{\prime} \mathrm{O}^{-1} \mathrm{Pr}$ Tol

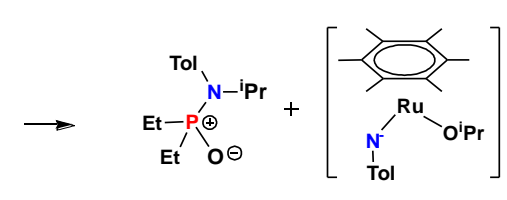

$4 b$

Scheme 3. Proposed mechanism of the formation of $4 b$. 


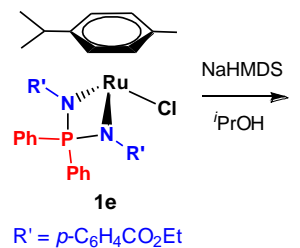

$\mathrm{R}^{\prime}=p-\mathrm{C}_{6} \mathrm{H}_{4} \mathrm{CO}_{2} \mathrm{E}$
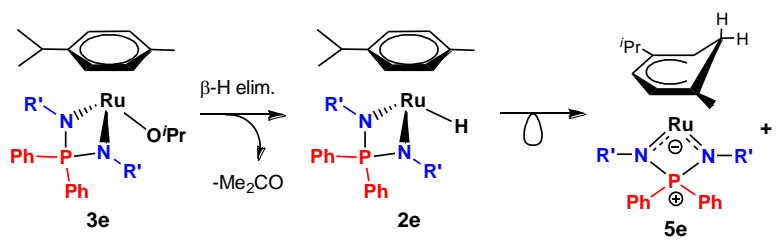

5 e

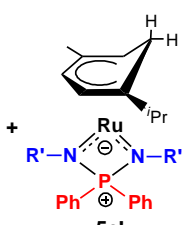

$5 e^{\prime}$

Scheme 4. Generation of the hydride $\mathbf{2 e}$ and its rearrangement to $5 \mathrm{e} / \mathbf{5} \mathrm{e}^{\prime}$

nucleophilic attack of the free isopropoxide-anion on the electrophilic phosphorus atom followed by the P-N bond cleavage and isopropyl group migration onto the nitrogen atom (Scheme 3). Once the excess of $\mathrm{O}^{i} \mathrm{Pr}^{-}$is consumed, $\mathbf{2} \mathbf{b}$ is rather stable in solution. This side reaction reduces the yield of the hydride complex $\mathbf{2} \mathbf{b}$, and affects the catalytic performance of $\mathbf{1 b}$ (see below). Unfortunately, even decreasing the amount of base to 1.0 equiv. did not suppress this side reaction completely, and besides $\mathbf{2 b}$, the product contained $20-60 \%$ of $\mathbf{4 b}$ in different experiments.

The reaction of $\mathbf{3 c}$ with isopropanol in the presence of a strong base (Figure S8) proceeds very quickly leading mostly to decomposition product, namely the aminophosphine oxide $\mathrm{Ph}_{2} \mathrm{P}(\mathrm{O})(\mathrm{NHMe})(\mathbf{4 c}, \delta 25.3)$. The isopropoxide complex $3 \mathrm{c}$ was not detected even after only $5 \mathrm{~min}$ after base addition. The corresponding hydride complex [( $\left.\left.\mathrm{C}_{6} \mathrm{Me}_{6}\right) \mathrm{RuH}\left(\mathrm{Ph}_{2} \mathrm{P}(\mathrm{NMe})_{2}\right)\right]$ (2c), characterized by a ${ }^{31} \mathrm{P} N M R$ signal at $\delta 49.8$ and RuH resonance at $\delta-4.12$ in ${ }^{1} \mathrm{H}$ NMR (Figure S8, insert), was observed in a relative amount lower than $10 \%$ while three additional minor impurities with ${ }^{31} \mathrm{P}$ NMR resonances at $\delta 32.8,47.6,52.7$ could not be identified. Complex $2 \mathrm{c}$ can alternatively be obtained by reacting $1 \mathrm{c}$ with 1 equiv. of $\mathrm{NaBHEt}_{3}$ in benzene- $\mathrm{d}_{6}$ (Figure S9a), ${ }^{25}$ presenting the same characteristic resonances at $\delta 49.8$ in ${ }^{31} \mathrm{P} N M R$ and at $\delta-4.09$ in ${ }^{1} \mathrm{H}$ NMR (Figure S9b). Thus the hydride complex $\mathbf{2 c}$ is indeed generated in the reaction of 1c with isopropoxide, however due to the highly basic $\mathrm{N}$ atoms ${ }^{27}$ it has very low stability in the presence of isopropanol, perhaps because of its facile protonation and further $\mathrm{P}-\mathrm{N}$ bond alcoholysis to form the aminophosphine oxide. Indeed, 1c slowly decomposes to aminophosphine oxide in isopropanol even in the absence of a base at room temperature (Figure S10).

Complex 1d, having only one basic N-Me group, reacts with basic isopropanol in a much cleaner way (Figure S11) to give predominantly the hydride complex $\mathbf{2 d}$ via the isopropoxide intermediate $\mathbf{3 d}$, which is observed in the first minutes at $\delta 46.6$ in the ${ }^{31} \mathrm{P}$ NMR spectrum. Complex $\mathbf{2 d}$ decomposes in the presence of isopropanol more slowly than $\mathbf{2 c}$, and therefore was characterized in situ by ${ }^{31} \mathrm{P}$ NMR $(\delta 41.3)$ and ${ }^{1} \mathrm{H}$ NMR $\left(\delta_{\mathrm{RuH}}-\right.$
3.72) (Figure S12). After 3 days, 2d was almost completely decomposed to aminophosphine oxide $\mathrm{Ph}_{2} \mathrm{P}(\mathrm{O})$ (NHMe) (4d, $\delta$ 25.3) and iminophosphonamine $D(\delta$ 4.0), plus unknown compounds with ${ }^{31} \mathrm{P}$ NMR signals at $\delta 35.5$ and 8.7 , apparently due to protonation of the NMe group, followed by NPN ligand decoordination and alcoholysis.

The formation of the hydride complex $[(p-$ Cymene)RuH( $\left.\mathrm{Ph}_{2} \mathrm{P}\left(\mathrm{NAr}^{*}\right)_{2}\right)$ ] (2e) is slower than that of the known $p$-cymene hydride $\mathbf{2 f},{ }^{25}$ due to the presence of acceptor substituents in the $\mathrm{N}$-Aryl groups (Figure $\mathrm{S} 13)$. The isopropoxide intermediate $\left[(p\right.$-Cymene $\left.) \mathrm{Ru}\left(\mathrm{O}^{\mathrm{i} P r}\right)\left(\mathrm{Ph}_{2} \mathrm{P}\left(\mathrm{NAr}^{*}\right)_{2}\right)\right] \quad$ (3e), characterized by a ${ }^{31} \mathrm{P}$ resonance at $\delta 43.2$, was still present after $2 \mathrm{~h}$ at room temperature and could be characterized by ${ }^{1} \mathrm{H}$ NMR (Figure S14). Complex $\mathbf{2 e}$ is relatively stable and was characterized in situ by ${ }^{31} \mathrm{P}$ and ${ }^{1} \mathrm{H}$ NMR (Figure S15). However, it slowly isomerizes to the mixture of cyclohexadienyl complexes $\mathbf{5 e}, \mathbf{5} \mathbf{e}^{\prime}\left(\delta_{\mathrm{P}} 53.3,53.7\right.$, Figure $\mathrm{S} 13$ ), similarly to $\mathbf{2 f}$ (Scheme 4).

It is noteworthy that excess of base ( $>1$ equiv. NaHMDS) results in a concomitant transesterification of the carboethoxy substituents to form mono- (2e') and di- (2e") carboisopropoxy derivatives, ultimately giving the mixture of the hydride complexes [( $p$-Cymene $\left.) \mathrm{RuH}\left(\mathrm{Ph}{ }_{2} \mathrm{P}\left(\mathrm{N}-p-\mathrm{C}_{6} \mathrm{H}_{4} \mathrm{COOR}\right)_{2}\right)\right]\left(\mathrm{R}=\mathrm{Et},{ }^{\mathrm{i}} \mathrm{Pr}\right)$ (Figure S16).

To summarize, the above experiments demonstrate that the reaction of 1a-e with sodium isopropoxide leads to the corresponding hydride complexes 2a-e, apparently, via isopropoxide intermediates, similarly to what was observed earlier for $\mathbf{2} \mathbf{f}$. However, the stability of $\mathbf{2 a - e}$ under the reaction conditions differs strongly from $\mathbf{2 a}$ (stable for days) to hardly observable 2c. Among the hexamethylbenzene complexes 2a-d, those with more basic $\mathbf{N}$-atoms, $\mathbf{2 c}$ and $\mathbf{2 d}$, are less stable due to facile protonation and alcoholysis by isopropanol. Although $\mathbf{2 b}$ appeared to be of comparably high stability as $\mathbf{2 a}$, the sterically more accessible phosphorus atom in this NPN ligand is prone to $\mathrm{O}^{\prime} \mathrm{Pr}$ nucleophilic attack, resulting in partial degradation of the intermediate $\mathbf{3} \mathbf{b}$ to the aminophosphine oxide $\mathbf{4 b}$, thus reducing the yield of the hydride complex $\mathbf{2} \mathbf{b}$.
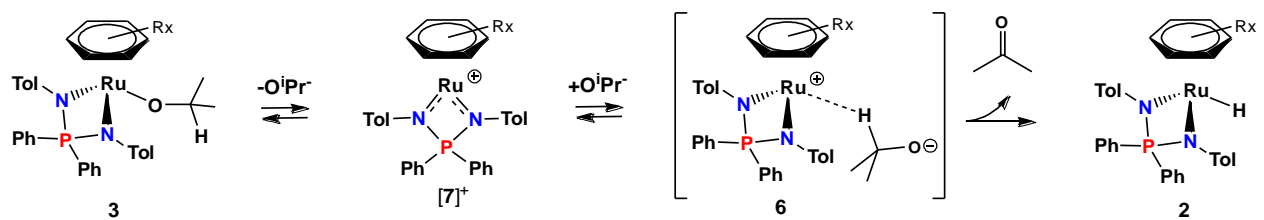

Scheme 5. Generation of the hydrides $\mathbf{2}$ via dissociation of $\mathrm{O}^{\mathrm{P} P r}$ from $\mathbf{3}$ followed by rotation and hydride transfer. 
Table 1. Results of the catalytic transfer hydrogenation of acetophenone by 1a-f. ${ }^{[a]}$

\begin{tabular}{|c|c|c|c|c|c|c|c|c|}
\hline \multirow{2}{*}{$\begin{array}{c}\text { Precat } \\
\text { alyst }\end{array}$} & \multirow{2}{*}{$\begin{array}{l}t_{\text {inc, }} \\
\min \end{array}$} & \multicolumn{6}{|c|}{ Conversion, \% } & \multirow{2}{*}{$k_{\text {obs }}, h^{-1}$} \\
\hline & & $0.5 \mathrm{~h}$ & $1 \mathrm{~h}$ & $1.5 \mathrm{~h}$ & $2 \mathrm{~h}$ & $3 \mathrm{~h}$ & $4 \mathrm{~h}$ & \\
\hline $1 a$ & 120 & 4.9 & 8.6 & 12.8 & 15 & 22.6 & 26.5 & 0.082 \\
\hline 1b & 60 & 2.7 & 4.4 & 6.1 & 9.8 & 13.3 & 17.3 & 0.048 \\
\hline $1 c^{[b]}$ & 5 & 16.3 & 27.7 & 35.5 & 40.1 & 44.5 & 45.4 & 0.354 \\
\hline 1d & 5 & 6.4 & 13.3 & 18.4 & 22.3 & 28.4 & 30.5 & 0.133 \\
\hline $1 e$ & 30 & 5.1 & 9.2 & 11.1 & 16.3 & 24.1 & 31.7 & 0.100 \\
\hline $1 f^{[c]}$ & 15 & 15.9 & 26.8 & 38.2 & 48 & 64.3 & 74.9 & 0.336 \\
\hline
\end{tabular}

[a] Standard conditions : $233 \mu \mathrm{L}$ of acetophenone ( $2 \mathrm{mmol}$ ) and $226 \mu \mathrm{L}$ of internal standard (dodecane) in $5 \mathrm{~mL}$ of solvent ([PhCOMe] $\left.=3.66 \cdot 10^{-1} \mathrm{M}\right), 0.02 \mathrm{mmol}$ of Ru catalyst $\left.\left([\mathrm{Ru}]=4 \cdot 10^{-3} \mathrm{M}\right)\right) ; 15 \mu \mathrm{L}$ NaHMDS $\left(2 \mathrm{M}\right.$ in THF), $\mathrm{NaHMDS} / \mathrm{Ru}=1.5 ; t_{\mathrm{inc}}-$ the conditioning time $@ 40^{\circ} \mathrm{C}$ before the substrate addition, $k_{\text {obs }}$ - the pseudo-first order rate constant. [b] $0.01 \mathrm{mmol}$ of Ru catalyst $\left([\mathrm{Ru}]=2 \cdot 10^{-3} \mathrm{M}\right)$ ). [c] Results from ref. ${ }^{25}$

Owing to the bulkier arene ligand, the hexamethylbenzene complex $\mathbf{3 a}$ undergoes $\boldsymbol{B}$-hydride elimination at a considerably slower rate than its $p$-cymene counterpart $3 \mathbf{f},{ }^{25}$ while this also prevents the corresponding hydride species $\mathbf{2 a}$ from transforming to the isomeric $16 \bar{e} \quad \eta^{5}$-cyclohexadienyl complexes, unlike the $p$-cymene complexes $\mathbf{2 e}$ and $\mathbf{2 f}$. The electron-withdrawing $\mathrm{N}$-substituents in $\mathbf{3}$ retard the $\beta$-hydride elimination to $\mathbf{2}$ ( $\mathbf{3 e}$ vs $\mathbf{3} \mathbf{f}$ and $\mathbf{3 a}$ vs $\mathbf{3 c}$ and $\mathbf{3 d}$ ) and is in line with observations about the chloride exchange rates in complexes $1 .{ }^{26}$ As we have proposed recently for the $p$-cymene hydride complex $\mathbf{2} \mathbf{f},{ }^{25}$ the generation of $\mathbf{2}$ requires isopropoxide ligand dissociation to the corresponding cationic species 6 and [7] the intermediate and the resting state in this process, respectively (Scheme 5).

\section{(c) Transfer hydrogenation of acetophenone catalysed by 1a-e.}

All the complexes 1a-e have been tested in transfer hydrogenation of acetophenone in isopropanol with addition of 1.5 equiv. NaHMDS at $40^{\circ} \mathrm{C}$ and the results were compared to those reported for $\mathbf{1} \mathbf{f}^{25}$ (Table 1). The conditions (temperature, incubation time after the addition of base) used for the generation of the catalytically active hydride complexes (2a-f) were in accordance with the model experiments described
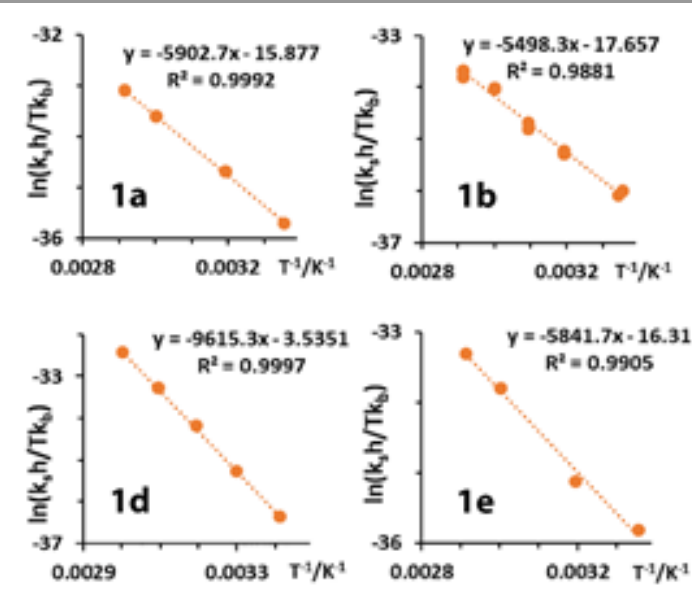

Figure 4. Eyring analysis of the second order rate constant $k_{\mathrm{s}}$ of the acetophenone transfer hydrogenation in isopropanol catalyzed by $\mathbf{1 a}, \mathbf{1} \mathbf{b}, \mathbf{1 d}, \mathbf{1 e}$ in the presence of base at different temperatures. Reaction conditions as in Table 1. above. It is important to underline that the incubation period is needed to quantitatively transform the precatalyst $\mathbf{1}$ to the active species $\mathbf{2}$. Notably, we have no evidence of darkening of the solution with formation of metallic nanoparticles (in fact, the solution colour becomes fainter as the hydrides $\mathbf{2}$ are less intensely coloured than the corresponding precursors $\mathbf{1}$ ).

The nature of the $\mathrm{N}$-substituents and $\eta^{6}$-arene affects the initial acetophenone hydrogenation rate, which is in qualitatively accordance with the rate of $\beta-\mathrm{H}$ elimination from 3 to 2: more donating $\mathrm{N}$-groups and less bulky arene significantly improve the catalyst performance. The lowered activity of $\mathbf{1} \mathbf{b}$ compared to $\mathbf{1 a}$ is due to partial decomposition of the precatalyst during generation of the hydride species $\mathbf{2} \mathbf{b}$, as mentioned in section (b). Similarly, the rapid activity decay observed when using $\mathbf{1 c}$ is caused by stability issues for $\mathbf{2 c}$.

For each complex, the kinetic data at different temperatures (Figure S17) were obtained to calculate the activation parameters of the reaction from Eyring plots (Figure 4). The low stability of 1c in basic isopropanol, especially at elevated temperatures, did not allow us to run an Eyring analysis for this system as it rapidly degraded above $40^{\circ} \mathrm{C}$ (Figure S17c). For $\mathbf{2 b}$ the catalytic results were less repeatable, therefore for building the Eyring plot we used the average of the two most consistent rate constants obtained at each temperature.

For catalyst 1f, kinetic experiments with different [Ru] had demonstrated that the rate law is first order in catalyst, as well as first order in ketone. ${ }^{25}$ For complexes 1a-e, we have therefore assumed the same rate law and no additional kinetic experiments with variation of [Ru] were carried out. The activation enthalpy $\Delta H^{\neq}$and entropy $\Delta S^{\neq}$data for the ratedetermining step thus obtained are summarized in Table 2 .

The activation parameters obtained in the presence of the $\mathrm{N}$-Aryl substituted precatalysts $(\mathbf{1} \mathbf{a}, \mathbf{1} \mathbf{b}, \mathbf{1 e}, \mathbf{1} \mathbf{f})$ are within narrow ranges $\left(9.7-11.7 \mathrm{kcal} / \mathrm{mol}\right.$ for $\Delta H^{\neq}$and $31-35 \mathrm{cal} /(\mathrm{mol} \cdot \mathrm{K})$ for $\left.\Delta S^{\ddagger}\right)$. This suggests the occurrence of a similar catalytic mechanism for these complexes, which apparently involves the hydride species $\mathbf{2}$ and the zwitterionic intermediate $\mathbf{6}$ as previously investigated by a combination of experimental and computational methods for the $\mathbf{1 f}$ system..$^{25}$ The activation enthalpies for 1a and 1e are meaningfully higher than that for 1f, in line with the retardation effect of the bulkier $\mathrm{C}_{6} \mathrm{Me}_{6}$ arene ligand and the electron-withdrawing $\mathrm{N}$-substituents.

The activation parameters found for complex $\mathbf{1 d}$, on the other hand, differ significantly. The higher $\Delta H^{\neq}(19.1 \pm 0.8$ $\left.\mathrm{kcal} \cdot \mathrm{mol}^{-1}\right)$ and the smaller negative $\left.\Delta S^{\neq}\left(-7 \pm 3 \mathrm{cal} \cdot \mathrm{mol}^{-1} \cdot \mathrm{K}^{-1}\right)\right)$ are indicative of a different rate-determining transition state, less highly ordered than for the bis-N-Aryl complexes. Therefore,

Table 2. The activation parameters of acetophenone hydrogenation with
complexes $\mathbf{1 a}-\mathbf{f}$ in the presence of base.
\begin{tabular}{cccccccc}
\hline 1a & 1b & 1c & 1d & 1e & 1 f* \\
\hline$\Delta \mathrm{H}^{\neq}, \mathrm{kcal} \cdot \mathrm{mol}^{-1}$ & $11.7 \pm 1$ & $10.9 \pm 1$ & - & $19.1 \pm 0.8$ & $11.6 \pm 1$ & $9.7 \pm 1$ \\
$\Delta \mathrm{S}^{\neq}, \mathrm{cal} \cdot\left(\mathrm{mol}^{-1} \cdot \mathrm{K}^{-1}\right)$ & $-32 \pm 4$ & $-35 \pm 5$ & - & $-7 \pm 3$ & $-32 \pm 4$ & $-31 \pm 4$ \\
\hline
\end{tabular}

* The data for $\mathbf{1} \mathbf{f}$ is given for comparison from ${ }^{25}$.

the N-Me substituted complexes $\mathbf{1 c}$ and $\mathbf{1 d}$ are supposedly 
promote an alternative hydrogenation mechanism, the elucidation of which required additional kinetic experiments and DFT calculations.

\section{(d) Acetophenone transfer hydrogenation mechanism in the} absence of base.

Whereas systems $\mathbf{1 a}, \mathbf{1} \mathbf{b}, \mathbf{1 e}$ and $\mathbf{1} \mathbf{f}^{25}$ require the presence of a strong base for activity, the precatalysts $\mathbf{1 c}$ and $\mathbf{1 d}$ demonstrate high activity even without a base. The acetophenone hydrogenation kinetic curves catalysed by $\mathbf{1 c}$ and $\mathbf{1 d}$ in neat isopropanol at different temperatures are shown in Figure 5. In fact, these complexes are much more stable under the reaction conditions when a base is not present and can catalyse the hydrogenation process for longer times and at higher temperatures. However, this stability increase is still insufficient to yield perfectly repeatable results for system $\mathbf{1 c}$, as reflected in the lower precision of the Eyring analysis. The activation parameters obtained from the Eyring analysis are $\Delta H^{\neq}=24 \pm 5$ (1c), $22.5 \pm 0.5$ (1d) $\mathrm{kcal} / \mathrm{mol}$ and $\Delta S^{\neq}=12 \pm 10$ (1c), $4 \pm 3$ (1d) $\mathrm{kcal} /(\mathrm{mol} \cdot \mathrm{K})$. Note that the activation parameters obtained for 1d with and without base are close to each other.

An interesting observation is that the dissolution of both $\mathbf{1 c}$ and $\mathbf{1 d}$ in isopropanol immediately leads to dissociation to the corresponding $16 \overline{\mathrm{e}}$ complexes $\left[\left(\eta^{6}-\mathrm{C}_{6} \mathrm{Me}_{6}\right) \mathrm{Ru}(\mathrm{NPN})\right]^{+} \mathrm{Cl}^{-}\left([7 \mathrm{c}]^{+}\right.$ and $[\mathbf{7 d}]^{+}$, respectively), which is reflected by the colour change from red to purple and the downfield shift of the ${ }^{31 P} \mathrm{PMR}$ resonance from $\delta 59.8$ to 77.8 for $1 c^{26}$ and from $\delta 52.0$ to 68.4 for 1d (Figure S18). This behaviour differs from that of the chloro derivatives $\mathbf{1 a}, \mathbf{1 e}$ and $\mathbf{1}$, which maintain their neutral
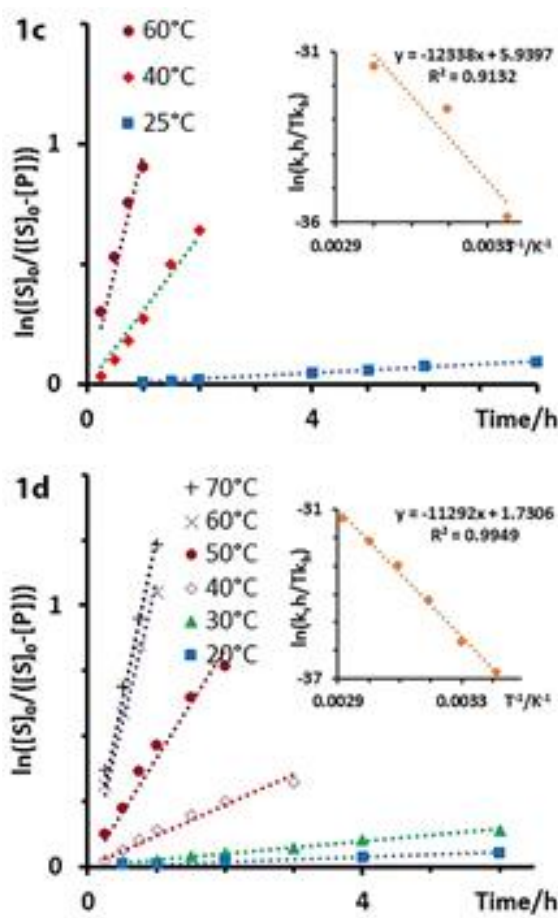

Figure 5. First order kinetics analyses of the acetophenone transfer hydrogenation in neat isopropanol catalysed by $\mathbf{1 c}, \mathbf{1} \mathbf{d}$ at different temperatures. Reaction conditions: complex 1c $\left(0.01 \mathrm{mmol},[\mathrm{Ru}]=2 \cdot 10^{-3} \mathrm{M}\right)$, complex $1 \mathbf{d}(0.02 \mathrm{mmol}$, [Ru] $\left.=4 \cdot 10^{-3} \mathrm{M}\right)$, acetophenone $(233 \mu \mathrm{l}, 2 \mathrm{mmol})$, isopropanol $(5 \mathrm{ml})$. [PhCOMe] $=$ $3.7 * 10^{-1} \mathrm{M}$. (insert) Eyring analysis of the second order rate constant $k_{\mathrm{s}}$. state under the same conditions and only produce the corresponding $16 \overline{\mathrm{e}}$ complexes when a reagent is added to scavenge the chloride ion. These cationic complexes [7c] ${ }^{+}$and [7d] ${ }^{+}$are apparently the catalyst resting state, since they are the major identified species by ${ }^{31} \mathrm{P}$ NMR during the transfer hydrogenation catalysis. Although $\mathbf{1 b}$ also dissociates in ${ }^{i} \mathrm{PrOH}$ to cationic complex [ $\mathbf{7 b}]^{+}$, its catalytic performance is very poor yielding $4.5 \%$ conversion of acetophenone after $24 \mathrm{~h}$ at $40^{\circ} \mathrm{C}$. It should also be mentioned that, as shown in our previous contribution, ${ }^{25}$ compound $\mathbf{1 f}$ is stoichiometrically transformed to the catalytically active hydride complex $2 \mathbf{f}$ in situ by the strong base in $\mathrm{iPrOH}$, hence the same process can be proposed for the other chloride complexes. Since the hydride complexes

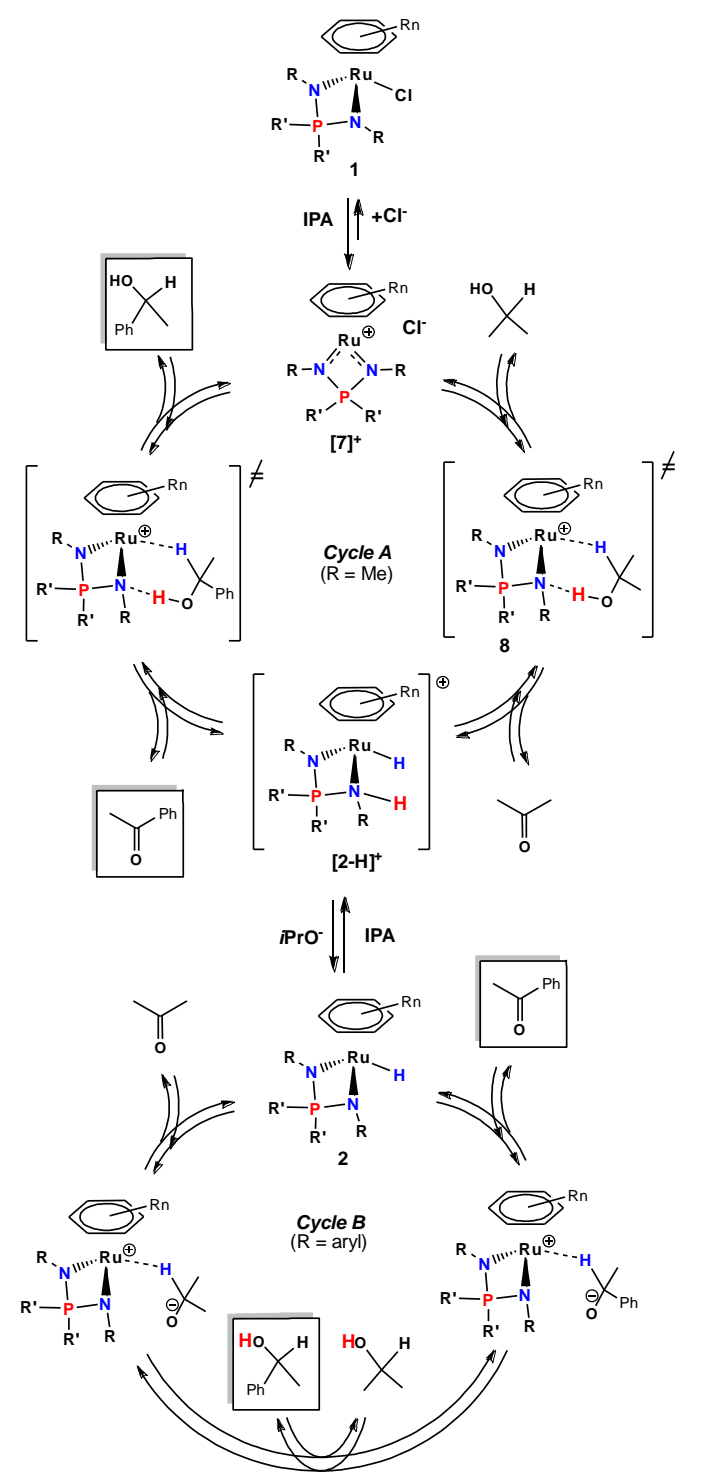

Scheme 6. Two possible mechanisms of acetophenone hydrogenation catalyzed by ruthenium iminophosphonamides depending on the basicity of the $\mathrm{N}$-atoms. 
cannot be isolated, a slight excess of base (up to 1.5 equiv) is generally used. In one case (catalyst 1f) the 1f/NaHMDS ratio was varied (1/1 and $1 / 2)$ but the observed rate constant was essentially identical $\left(0.095\right.$ and $0.106 \mathrm{~h}^{-1}$, respectively, at $\left.25^{\circ} \mathrm{C}\right)$ Thus, whereas a first equivalent of base is needed to activate $\mathbf{1 a}, \mathbf{1 b}, \mathbf{1 e}$ and $\mathbf{1} \mathbf{f}$, it appears that the excess amount has no effect on the catalytic cycle.

\section{(e) Mechanistic discussion.}

The possibility of a Meerwin-Ponndorf-Verley (MPV) mechanism can be easily discarded for two reasons: $(i)$ the catalyst works under base-free conditions, whereas the MPV pathways requires alkoxide binding to the catalyst; (ii) these catalysts cannot offer a second open coordination site for coordination of the ketone substrate because of the strong chelating power of the NPN ligand. Taking into account the MeN high basicity in the $18 \bar{e}$ ruthenium complexes with ligands $C$ and D, we propose that the acetophenone hydrogenation in neat isopropanol follows the classical Noyori mechanism ${ }^{14}$, in which a simultaneous transfer of the isopropanol methyne $\mathrm{H}$ atom to the $\mathrm{Ru}$ atom and of the $\mathrm{OH}$ proton to the basic $\mathrm{N}$ atom occurs through a pericyclic transition state in the rate-determining step (cycle $A$ in Scheme 6). We suppose that the protonated hydride complex $\left[\mathbf{2}-\mathrm{H}^{+}\right]$might be the true catalytically active species, having a relatively high energy and therefore being present in the catalytic system in a low stationary state concentration. For the less basic aryl-substituted NPN systems, on the other hand, an external base is necessary and the reaction occurs via cycle $\mathbf{B}$, implicating the neutral hydride complex $\mathbf{2}$, as validated by a
DFT study in our previous contribution. ${ }^{25}$

When the transfer hydrogenation is catalysed by complex 1c or $\mathbf{1} \mathbf{d}$ in the presence of a base, the resting state is the hydride complex (2c or $\mathbf{2 d}$, respectively) rather than the cationic complex $\left([\mathbf{7 c}]^{+}\right.$or $[\mathbf{7 d}]^{+}$, respectively). NMR monitoring of the hydride complex $\mathbf{2 d}$ in the presence of $\mathrm{PrOH}$ (10 equiv) in $\mathrm{C}_{6} \mathrm{D}_{6}$ indicates no change (see Figure S19), hence no spontaneous proton transfer with formation of $[\mathbf{2}-\mathbf{H}]^{+}$with an PrO- $^{-}$ counterion. Addition of acetophenone to this solution at room temperature only showed the slow formation of the 1phenylethanol product (see Figure S20), without any change for the resonances of $\mathbf{2}$. This means that $\mathbf{2}$ is an off-loop resting state under these conditions.

In order to validate this proposition, new DFT calculations were carried out for the proposed cycle $A$. The results, shown in Figure 6 , suggest that the proposed mechanism is indeed accessible. The calculations were carried out at the same level of theory as those previously presented for cycle B (see details in the Experimental section), ${ }^{25}$ using the full NPN ligand and a benzene ring to model the real arene ligand and included corrections for solvation effects by use of a polarizable continuum in isopropanol and for dispersion effects during optimization. Only the catalyst activation step, involving $\mathrm{H}_{2}$ delivery to $\left[\mathbf{7}^{+}\right.$from isopropanol to generate $[\mathbf{2 - H}]^{+}$and acetone, was analysed. The energetic profile of the subsequent delivery of $\mathrm{H}_{2}$ to acetophenone, which occurs symmetrically in the reverse direction, should be quite similar. The first step of this process is the chloride ion dissociation from 1 . To render the calculated model closer to reality, explicit solvation of the chloride ion by $\mathrm{H}$-bonding interactions with three solvent

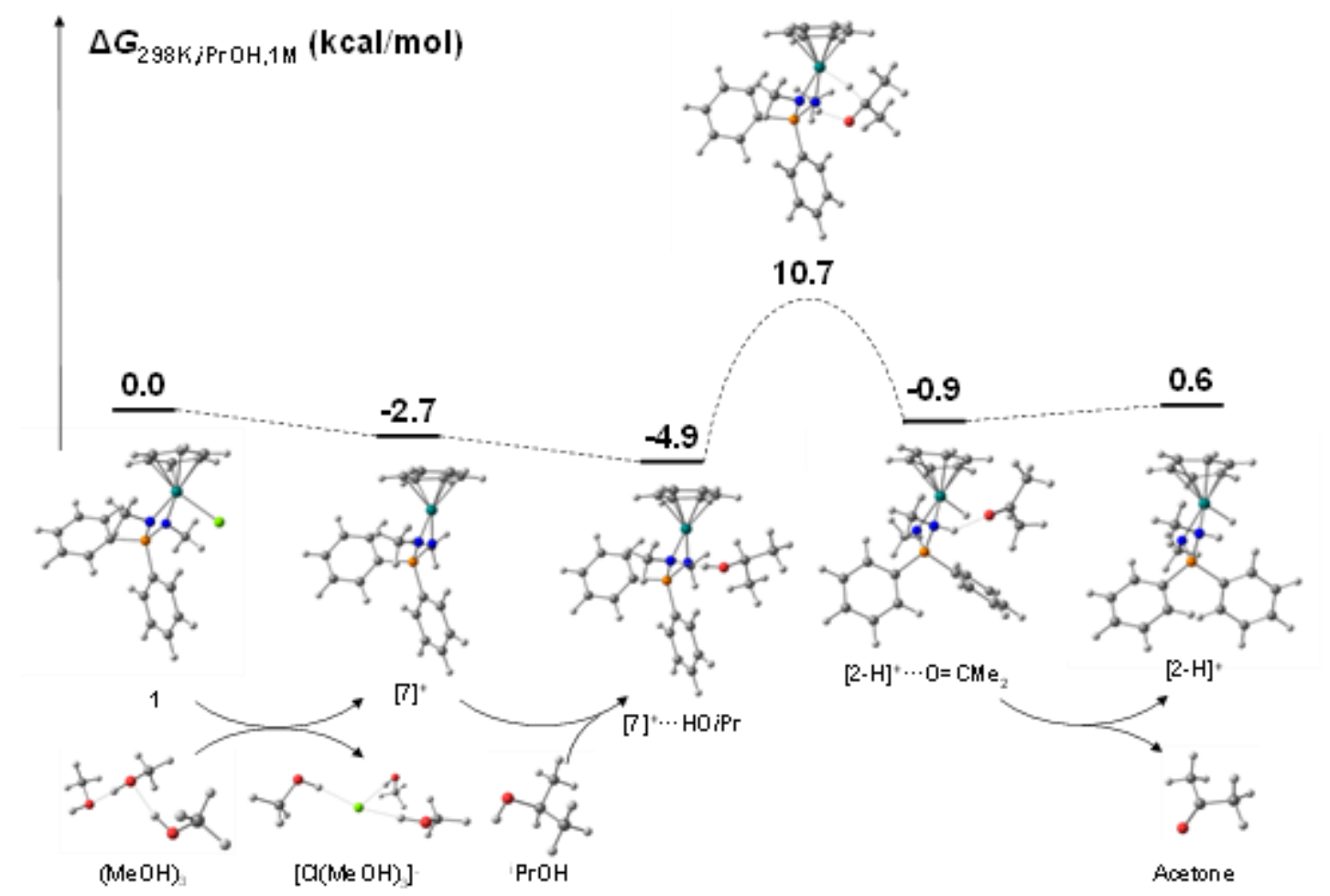

Figure 6. Free energy profile for the dissociation of the model $\left[\left(\mathrm{C}_{6} \mathrm{H}_{6}\right) \mathrm{Ru}(\mathrm{NPN}) \mathrm{Cl}\right]$ complex in $i \mathrm{PrOH}$ and for the generation of the catalytically active $\left[\left(\mathrm{C}_{6} \mathrm{H}_{6}\right) \mathrm{RuH}(\mathrm{NPNH})\right]^{+}$ complex (NPN = MeNPPh $\left.{ }_{2} \mathrm{NMe}\right)$. 
molecules (modelled by methanol) were considered, yielding a slightly exoergic process. This in agreement with the experimental evidence (see above). The isopropanol molecule first docks onto the NPN ligand by establishing an $\mathrm{H}$-bond as a proton donor with one of the two NMe groups, yielding $[7]^{+\ldots H O i P r}$ through a second slightly exoergic process. Then, the proton is transferred to the NMe group and the methyne $\mathrm{H}$ atom is simultaneously transferred to the Ru centre to become a hydride ligand and yield the $\mathrm{H}$-bonded adduct between [2-H] $]^{+}$ (proton donor) and acetone (proton acceptor), via a first-order saddle point $(20.3 \mathrm{i} \mathrm{cm}-1)$ located at only $10.7 \mathrm{kcal} / \mathrm{mol}$ above the starting complex 1 and $15.6 \mathrm{kcal} / \mathrm{mol}$ above system [7] $]^{+\ldots} \mathrm{HO} \mathrm{Pr}$. An IRC analysis demonstrates that this concerted proton/hydride transfer is quite asynchronous, the proton transfer occurring on the upslope from [7]+... HOiPr to the saddle point, whereas the hydride transfer process takes place around the saddle point. Dissociation of the $\mathrm{H}$-bonded adduct yield separate $[\mathbf{2}-\mathbf{H}]^{+}$and acetone in a nearly isoergic process. Finally, DFT calculations were carried out to assess the stability of [2$\mathbf{H}]^{+}$with respect to proton transfer processes to either the isopropoxide ion or isopropanol (modelled by methoxide and methanol, respectively). In order to satisfactorily model the strong base in the alcohol solvent, the $\mathrm{H}$-bonded adduct with three solvent molecules, $\left[\mathrm{MeO}(\mathrm{MeOH})_{3}\right]^{-}$was used, leading to a $(\mathrm{MeOH})_{4}$ cluster and the neutral hydride 2. The calculations yield an exoergic process with $\Delta G_{\mathrm{iProH}}=-6.4 \mathrm{kcal} / \mathrm{mol}$, in agreement with the experimental observation that $\mathbf{2}$ is stable in $i \mathrm{PrOH}$ (in other words, $i \mathrm{PrOH}$ is not able to protonate $\mathbf{2}$ and generate $\left.[\mathbf{2}-\mathbf{H}]^{+}\right)$. Therefore, the calculation confirm that $\mathbf{2}$ is the catalyst resting state when generated from $\mathbf{1}$ in the presence of a strong base. Conversely, proton transfer from $[2-\mathrm{H}]^{+}$to the solvent, modelled by the $(\mathrm{MeOH})_{3}$ cluster, to yield 2 and $\left[\mathrm{MeOH}_{2}(\mathrm{MeOH})_{2}\right]^{+}$is highly endoergic $\left(\Delta G_{\mathrm{iPrOH}}=21.0 \mathrm{kcal} / \mathrm{mol}\right)$. This means that $[\mathbf{2}-\mathbf{H}]^{+}$is stable, i.e. is not deprotonated, in the absence of the strong base. Thus, according to Figure 6 , the resting state of the catalyst is $\left[\mathbf{7}^{+}\right.$. The likely rate-determining step is the conversion of [7] $]^{+\ldots} \mathrm{HO}$ Pr to $[\mathbf{2}-\mathrm{H}]^{+\ldots} \mathrm{O}=\mathrm{CMe}_{2}$, for a calculated free energy span of $15.6 \mathrm{kcal} / \mathrm{mol}$. For system d, the experimentally determined activation parameters $\left(\Delta H^{\ddagger}=\right.$ $19.1 \pm 0.8 \mathrm{kcal} \cdot \mathrm{mol}^{-1}$ and $\Delta S^{\ddagger}=-7 \pm 3 \mathrm{cal} \cdot \mathrm{mol}^{-1} \cdot \mathrm{K}^{-1}$ ) yield a $\Delta G^{\ddagger}$ of $21.2 \mathrm{kcal} / \mathrm{mol}$ at $298 \mathrm{~K}$. The value estimated by DFT is even lower and is thus quite consistent with the feasibility of this concerted pathway. The underestimation of the cycle $\Delta G^{\ddagger}$ by the DFT calculations may be related at least in part to the small benzene model, which imposes lower steric constraints on the concerted transition state relative to the larger $\mathrm{C}_{6} \mathrm{Me}_{6}$ ring in system d. Inaccuracies in the solvation model and in the handling of the entropic contribution in the condensed phase can also contribute to the computational error.

\section{Experimental}

\section{General procedures.}

All manipulations were carried out using standard Schlenk techniques under an atmosphere of dry argon. Solvents were purified by standard methods and distilled prior to use. The assignment of the resonances for the complexes $\mathbf{1}$ and $\mathbf{2}$ was based on the analysis of ${ }^{31} \mathrm{P},{ }^{1} \mathrm{H},{ }^{13} \mathrm{C}\left\{{ }^{1} \mathrm{H}\right\},{ }^{1} \mathrm{H}-{ }^{1} \mathrm{H}$ COSY and ${ }^{1} \mathrm{H}-{ }^{13} \mathrm{C}$ HSQC NMR spectra. ${ }^{1} \mathrm{H},{ }^{31} \mathrm{P}$ and ${ }^{13} \mathrm{C}$ NMR spectra were obtained on Bruker Avance $\mathbf{3 0 0}$ and Bruker Avancelll 400 spectrometers and referenced to the residual signals of deuterated solvent $\left({ }^{1} \mathrm{H}\right.$ and ${ }^{13} \mathrm{C}$ ), and to $85 \% \mathrm{H}_{3} \mathrm{PO}_{4}\left({ }^{31} \mathrm{P}\right.$, external standard). Complexes $\left[\left(\eta^{6}-\mathrm{C}_{6} \mathrm{Me}_{6}\right) \mathrm{RuCl}_{2}\right]_{2}{ }^{30}\left[\left(\eta^{6}-\mathrm{Cym}\right) \mathrm{RuCl}_{2}\right]_{2}{ }^{31}$ the iminophosphonamines $\mathbf{A}-\mathbf{C}^{27} \mathbf{D}^{29}$ and $\left[\mathrm{Ph}_{2} \mathrm{P}\left(\mathrm{NH}-p-\mathrm{C}_{6} \mathrm{H}_{4} \mathrm{COOEt}\right)_{2}\right] \mathrm{Br}^{28}$ were prepared according to described procedures.

\section{Synthesis of $\mathrm{Ph}_{2} \mathrm{P}\left(\mathrm{NHAr}^{*}\right)$ (NAr*) $\left(\mathrm{Ar}^{*}=p-\mathrm{C}_{6} \mathrm{H}_{4} \mathrm{COOEt}\right)(\mathrm{E})$. To a} suspension of $\left[\mathrm{Ph}_{2} \mathrm{P}\left(\mathrm{NHAr}^{*}\right)_{2}\right] \mathrm{Br}(1.25 \mathrm{~g}, 2.10 \mathrm{mmol})$ in benzene $(40 \mathrm{~mL})$, neat $\mathrm{Et}_{2} \mathrm{NH}(0.24 \mathrm{~mL}, 2.2 \mathrm{mmol})$ was added and the mixture was stirred for $2 \mathrm{~h}$. The precipitate was filtered off and the filtrate was evaporated to dryness. The residue was dissolved in diethyl ether $(20 \mathrm{~mL})$ and the product was precipitated with hexane $(40 \mathrm{~mL})$. The white crystalline precipitate was dried in vacuo (yield $=1.06 \mathrm{~g}, 98 \%$ ). Anal. calcd for $\mathrm{C}_{30} \mathrm{H}_{29} \mathrm{~N}_{2} \mathrm{O}_{4} \mathrm{P}: \mathrm{C}, 70.30 ; \mathrm{H}, 5.70 ; \mathrm{N}, 5.47 \%$. Found: $\mathrm{C}, 70.59$; $\mathrm{H}, 5.87 ; \mathrm{N}, 5.34 \% .{ }^{31} \mathrm{P}\left\{{ }^{1} \mathrm{H}\right\} \mathrm{NMR}\left(\mathrm{C}_{6} \mathrm{D}_{6}\right): \delta-5.3 .{ }^{1} \mathrm{H}$ NMR $\left(\mathrm{C}_{6} \mathrm{D}_{6}\right): \delta$ $8.01\left(\mathrm{~d}, 3^{3} \mathrm{JH}_{\mathrm{HH}}=8.4,4 \mathrm{H}, \mathrm{C}_{6} \underline{\mathrm{H}}_{4}\left(\mathrm{CO}_{2} \mathrm{Et}\right)\right), 7.91\left(\mathrm{ddd},{ }^{3} J_{\mathrm{HP}}=12.8,{ }^{3} J_{\mathrm{HH}}\right.$ $\left.=8.0,{ }^{4} J_{\mathrm{HH}}=1.8,4 \mathrm{H}, o-\mathrm{H}_{\mathrm{Ph}}\right), 7.22\left(\mathrm{~d},{ }^{3} \mathrm{~J}_{\mathrm{HH}}=8.4,4 \mathrm{H}, \mathrm{C}_{6} \underline{\mathrm{H}}_{4}\left(\mathrm{CO}_{2} \mathrm{Et}\right)\right)$, $6.97\left(\mathrm{~m}, 6 \mathrm{H},(m+p)-\mathrm{H}_{\mathrm{Ph}}\right), 6.29(\mathrm{~s}, 1 \mathrm{H}, \mathrm{NH}), 4.07\left(\mathrm{q},{ }^{3} \mathrm{~J}_{\mathrm{HH}}=7.2\right.$, $\left.4 \mathrm{H}, \mathrm{C}_{2} \underline{\mathrm{CH}_{3}}\right), 0.99\left(\mathrm{t},{ }^{3} \mathrm{~J}_{\mathrm{HH}}=7.2,6 \mathrm{H}, \mathrm{CH}_{2} \mathrm{C}_{3} \underline{3}\right) .{ }^{13} \mathrm{C}\left\{{ }^{1} \mathrm{H}\right\} \mathrm{NMR}$ $\left(\mathrm{C}_{6} \mathrm{D}_{6}\right): \delta 166.7$ (s, $\left.\underline{\mathrm{CO}}{ }_{2} \mathrm{Et}\right), 145.4\left(\mathrm{~s}, i-\mathrm{C}_{6} \mathrm{H}_{4}\left(\mathrm{CO}_{2} \mathrm{Et}\right)\right), 131.9$ (d, ${ }^{2} J_{\mathrm{CP}}$ $\left.=9.8, o-C_{P h}\right), 131.8\left(d,{ }^{4} J_{C P}=2.8, p-C_{P h}\right), 131.2(s, m-$ $\left.\mathrm{C}_{6} \mathrm{H}_{4}\left(\mathrm{CO}_{2} \mathrm{Et}\right)\right), 130.9\left(\mathrm{~d},{ }^{1} J_{\mathrm{CP}}=131.9, i-\mathrm{C}_{\mathrm{Ph}}\right), 128.6\left(\mathrm{~d},{ }^{3} J_{\mathrm{CP}}=12.3\right.$, $m$ - $\left.\mathrm{CPh}_{\mathrm{Ph}}\right), 122.1$ (br. s, $\left.p-\mathrm{C}_{6} \mathrm{H}_{4}\left(\mathrm{CO}_{2} \mathrm{Et}\right)\right), 120.2\left(\mathrm{~d},{ }^{3} J_{\mathrm{CP}}=18.3, o-\right.$ $\left.\mathrm{C}_{6} \mathrm{H}_{4}\left(\mathrm{CO}_{2} \mathrm{Et}\right)\right)$, 59.9 (s, $\left.\underline{\mathrm{CH}}_{2} \mathrm{CH}_{3}\right), 13.9\left(\mathrm{~s}, \mathrm{CH}_{2} \underline{\mathrm{CH}_{3}}\right)$.

Synthesis of $\left[\left(\eta^{6}-\mathrm{C}_{6} \mathrm{Me}_{6}\right) \mathrm{RuCl}\left\{\mathrm{Ph}_{2} \mathrm{P}(\mathrm{N}-\mathrm{p}-\mathrm{Tol})(\mathrm{NMe})\right\}\right]$ (1d). To a solution of iminophosphonamine $\mathbf{D}(0.32 \mathrm{~g}, 1.00 \mathrm{mmol})$ in benzene $(50 \mathrm{~mL})$ a $0.6 \mathrm{M}$ solution of NaHMDS in toluene (1.8 $\mathrm{mL}, 1.08 \mathrm{mmol}$ ) was added and the resulting solution was stirred for $2 \mathrm{~h}$ at room temperature. Then solid $\left[\left(\eta^{6}-\right.\right.$ $\left.\left.\mathrm{C}_{6} \mathrm{Me}_{6}\right) \mathrm{RuCl}_{2}\right]_{2}(0.34 \mathrm{~g}, 0.50 \mathrm{mmol})$ was added, and the reaction mixture was stirred overnight. The resulting solution was diluted with hexane $(50 \mathrm{~mL})$, and the precipitate was filtered off. The filtrate was concentrated to $5 \mathrm{~mL}$ and then hexane was added with small portions within $0.5 \mathrm{~h} \mathrm{(20} \mathrm{mL} \mathrm{in} \mathrm{total)} \mathrm{to} \mathrm{induce}$ crystallization. The precipitated orange-red crystals were filtered off, washed with hexane $(2 \times 5 \mathrm{~mL})$ and dried in vacuum (yield $=0.47 \mathrm{~g}, 77 \%$ ). Anal. calcd for $\mathrm{C}_{32} \mathrm{H}_{38} \mathrm{ClN}_{2} \mathrm{PRu}: \mathrm{C}, 62.18 ; \mathrm{H}$, 6.20\%. Found: $\mathrm{C}, 62.54 ; \mathrm{H}, 6.58 \% .{ }^{31} \mathrm{P}\left\{{ }^{1} \mathrm{H}\right\} \mathrm{NMR}\left(\mathrm{C}_{6} \mathrm{D}_{6}\right): \delta 52.04$. ${ }^{1} \mathrm{H}$ NMR $\left(\mathrm{C}_{6} \mathrm{D}_{6}\right)$ : $\delta 7.92\left(\mathrm{~m}, 4 \mathrm{H},\left(o+o^{\prime}\right)-\mathrm{H}_{\mathrm{Ph}}\right), 7.23$ (br. s, 3H, $(m+p)-$ $\left.\mathrm{H}_{\mathrm{Ph}}\right), 7.15\left(\mathrm{dd},{ }^{3} J_{\mathrm{HH}}=8.0,{ }^{4} J_{\mathrm{HP}}=1.2,2 \mathrm{H}, o-\mathrm{H}_{\mathrm{Tol}}\right), 6.91\left(\mathrm{~d},{ }^{3} J_{\mathrm{HH}}=8.0\right.$, $\left.2 \mathrm{H}, m-\mathrm{H}_{\mathrm{Tol}}\right), 6.87$ (br. s, 3H, $\left.(m+p)^{\prime}-\mathrm{H}_{\mathrm{Ph}}\right), 2.74\left(\mathrm{~d}, 3^{3} \mathrm{HP}_{\mathrm{HP}}=20.0,3 \mathrm{H}\right.$, MeN), 2.14 (s, 3H, Me $\left.{ }_{\text {Tol }}\right), 1.82\left(\mathrm{~s}, 18 \mathrm{H}, \mathrm{C}_{6} \mathrm{Me}_{6}\right) .{ }^{13} \mathrm{C}\left\{{ }^{1} \mathrm{H}\right\} \mathrm{NMR}$ $\left(\mathrm{C}_{6} \mathrm{D}_{6}\right): \delta 146.2\left(\mathrm{~d},{ }^{2} \mathrm{~J}_{\mathrm{CP}}=3.2, i-\mathrm{C}_{\mathrm{Tol}}(\mathrm{N})\right), 135.1$ (br. d, ${ }^{2} J_{\mathrm{CP}}=10.4, o^{-}$ $\left.\mathrm{C}_{\mathrm{Ph}}\right), 131.7$ (br. d, ${ }^{2} \mathrm{~J}_{\mathrm{CP}}=10.6, o^{\prime}-\mathrm{C}_{\mathrm{Ph}}$ ), 131.4 (br. $\left.\mathrm{s}, p-\mathrm{C}_{\mathrm{Ph}}\right), 131.0$ (br. s, $\left.p^{\prime}-C_{p h}\right), 127.8-128.0$ (overlapped, $\left.\left(m+m^{\prime}\right)-C_{p h}\right), 129.1(s, m-$ $\left.\mathrm{C}_{\mathrm{Tol}}\right), 127.0\left(\mathrm{~d},{ }^{5} J_{\mathrm{CP}}=1.3, p-\mathrm{C}_{\mathrm{Tol}}\right), 124.6\left(\mathrm{~d},{ }^{3} \mathrm{~J}_{\mathrm{CP}}=10.0, o-\mathrm{C}_{\mathrm{Tol}}\right), 89.3$ (s, $\left.\underline{\mathrm{C}}_{6} \mathrm{Me}_{6}\right), 32.8$ (s, MeN), 20.8 (s, Me $\left.\mathrm{Tol}_{\mathrm{Tol}}\right), 16.0$ (s, $\left.\mathrm{C}_{6} \underline{\mathrm{Me}}_{6}\right)$. Synthesis of $\left[\left(\eta^{6}-p\right.\right.$-cymene) RuCl $\left.\left\{\mathrm{Ph}_{2} \mathrm{P}\left(\mathrm{N}-p-\mathrm{C}_{6} \mathrm{H}_{4} \mathrm{COOEt}\right)_{2}\right\}\right]$ (1e). To a suspension of $\mathbf{E}(0.49 \mathrm{~g}, 0.96 \mathrm{mmol})$ in benzene $(40 \mathrm{~mL})$ a $0.6 \mathrm{M}$ solution of NaHMDS in toluene $(1.7 \mathrm{~mL}, 1.02 \mathrm{mmol})$ was added and the resulting solution was stirred for $1 \mathrm{~h}$ at room temperature. Then solid $\left[\left(\eta^{6}-p \text {-cymene }\right) \mathrm{RuCl}_{2}\right]_{2}(0.29 \mathrm{~g}, 0.48$ 
mmol) was added, and the reaction mixture was stirred overnight. The precipitate was filtered off, the filtrate was evaporated to $5 \mathrm{~mL}$ and then diluted with $30 \mathrm{~mL}$ of $\mathrm{Et}_{2} \mathrm{O}$. The orange crystalline precipitate was filtered off and washed with $\mathrm{Et}_{2} \mathrm{O}(3 \times 5 \mathrm{~mL}$ ), then dried in vacuo (yield $=0.69 \mathrm{~g}, 88 \%$ ). Anal. calcd for $\mathrm{C}_{40} \mathrm{H}_{42} \mathrm{ClN}_{2} \mathrm{O}_{4} \mathrm{PRu}$ : C, 61.42; $\mathrm{H}, 5.41 \%$. Found: C, 61.55; $\mathrm{H}, 5.54 \% .{ }^{31} \mathrm{P}\left\{{ }^{1} \mathrm{H}\right\} \operatorname{NMR}\left(\mathrm{C}_{6} \mathrm{D}_{6}\right): \delta 47.2 .{ }^{1} \mathrm{H}$ NMR $\left(\mathrm{C}_{6} \mathrm{D}_{6}\right): \delta 8.12(\mathrm{dd}$, $\left.{ }^{3} J_{\mathrm{HH}}=8.8,5 J_{\mathrm{HP}}=0.8,4 \mathrm{H}, \mathrm{C}_{6} \mathrm{H}_{4}\left(\mathrm{CO}_{2} \mathrm{Et}\right)\right), 7.98\left(\mathrm{ddd},{ }^{3} J_{\mathrm{HP}}=12.4,{ }^{3} J_{\mathrm{HH}}\right.$ $\left.=8.2,{ }^{4} J_{\mathrm{HH}}=1.4,2 \mathrm{H}, o-\mathrm{H}_{\mathrm{Ph}}\right), 7.87\left(\mathrm{ddd},{ }^{3} J_{\mathrm{HP}}=12.0,{ }^{3} J_{\mathrm{HH}}=8.2,{ }^{4} J_{\mathrm{HH}}\right.$ $\left.=1.4,2 \mathrm{H}, o^{\prime}-\mathrm{H}_{\mathrm{Ph}}\right), 7.23\left(\mathrm{td},{ }^{3} J_{\mathrm{HH}}=7.2,{ }^{4} J_{\mathrm{HP}}=1.6,1 \mathrm{H}, p-\mathrm{H}_{\mathrm{Ph}}\right), 7.19$ $\left(\mathrm{td},{ }^{3} J_{\mathrm{HH}}=7.2,{ }^{4} J_{\mathrm{HP}}=2.8,{ }^{4} J_{\mathrm{HH}}=1.6,2 \mathrm{H}, m-\mathrm{H}_{\mathrm{Ph}}\right), 7.13\left(\mathrm{dd},{ }^{3} J_{\mathrm{HH}}=\right.$ $\left.8.8,{ }^{4} J_{\mathrm{HP}}=0.8,4 \mathrm{H}, \mathrm{C}_{6} \mathrm{H}_{4}\left(\mathrm{CO}_{2} \mathrm{Et}\right)\right), 6.76\left(\mathrm{td},{ }^{3} J_{\mathrm{HH}}=7.6,{ }^{4} J_{\mathrm{HP}}=1.6\right.$, $\left.1 \mathrm{H}, p^{\prime}-\mathrm{H}_{\mathrm{Ph}}\right), 6.69\left(\mathrm{td},{ }^{3} J_{\mathrm{HH}}=7.6,{ }^{4} J_{\mathrm{HP}}=2.8,2 \mathrm{H}, m^{\prime}-\mathrm{H}_{\mathrm{Ph}}\right), 4.98(\mathrm{~d}$, $\left.3 J_{\mathrm{HH}}=6.0,2 \mathrm{H}, \mathrm{C}_{6} \mathrm{H}_{4}(\mathrm{Cym})\right), 4.82\left(\mathrm{~d},{ }^{3} \mathrm{~J}_{\mathrm{HH}}=6.0,2 \mathrm{H}, \mathrm{C}_{6} \mathrm{H}_{4}(\mathrm{Cym})\right)$, $4.17\left(\mathrm{q},{ }^{3} \mathrm{~J}_{\mathrm{HH}}=7.2,4 \mathrm{H}, \mathrm{CH}_{2} \mathrm{CH}_{3}\right), 2.67$ (sept, ${ }^{3} J_{\mathrm{HH}}=6.8,1 \mathrm{H}$, $\left.\mathrm{CHMe}_{2}\right), 1.69\left(\mathrm{~s}, 3 \mathrm{H}, \mathrm{Me}_{\text {cym }}\right), 1.04\left(\mathrm{t},{ }^{3} J_{\mathrm{HH}}=7.2,6 \mathrm{H}, \mathrm{CH}_{2} \underline{\mathrm{CH}}_{3}\right), 0.95$ $\left(\mathrm{d},{ }^{3} \mathrm{JHH}_{\mathrm{HH}}=6.8,6 \mathrm{H}, \mathrm{CHMe}{ }_{2}\right) \cdot{ }^{13} \mathrm{C}\left\{{ }^{1} \mathrm{H}\right\} \mathrm{NMR}\left(\mathrm{C}_{6} \mathrm{D}_{6}\right): \delta 166.5\left(\mathrm{~s}, \underline{\mathrm{CO}} \mathrm{O}_{2} \mathrm{Et}\right)$ $153.7\left(\mathrm{~d},{ }^{2} J_{\mathrm{CP}}=5.4, i-\underline{\mathrm{CN}}\left(\mathrm{CO}_{2} \mathrm{Et}\right)\right), 135.8\left(\mathrm{~d},{ }^{1} J_{\mathrm{CP}}=116.6, i^{\prime}-\mathrm{C}_{\mathrm{Ph}}\right)$, $134.8\left(d,{ }^{2} J_{\mathrm{CP}}=11.3, o^{\prime}-C_{P h}\right), 133.3\left(d,{ }^{1} J_{C P}=99.3, i-C_{P h}\right), 133.0(d$, $\left.{ }^{4} J_{\mathrm{CP}}=2.7, p^{\prime}-\mathrm{C}_{\mathrm{Ph}}\right), 132.6\left(\mathrm{~d},{ }^{4} J_{\mathrm{CP}}=2.5, p-\mathrm{C}_{\mathrm{Ph}}\right), 132.4\left(\mathrm{~d},{ }^{2} J_{\mathrm{CP}}=10.9\right.$, $\left.o-\mathrm{C}_{\mathrm{Ph}}\right), 130.9$ (s, $\left.m-\mathrm{C}_{6} \mathrm{H}_{4}\left(\mathrm{CO}_{2} \mathrm{Et}\right)\right), 129.1\left(\mathrm{~d},{ }^{3} \mathrm{JPP}_{\mathrm{CP}}=12.1, m-\mathrm{C}_{\mathrm{Ph}}\right)$, $128.6\left(\mathrm{~d},{ }^{3} \mathrm{~J}_{\mathrm{CP}}=12.3, m^{\prime}-\mathrm{C}_{\mathrm{Ph}}\right), 122.2\left(\mathrm{~d},{ }^{3} J_{\mathrm{CP}}=12.2, o-\mathrm{C}_{6} \mathrm{H}_{4}\left(\mathrm{CO}_{2} \mathrm{Et}\right)\right)$, $120.6\left(\mathrm{~s}, p-\mathrm{C}_{6} \mathrm{H}_{4}\left(\mathrm{CO}_{2} \mathrm{Et}\right)\right), 104.1\left(\mathrm{~s}, i-\mathrm{C}_{\mathrm{Cym}}\right), 95.7$ (s, $\left.i-\mathrm{C}_{\mathrm{Cym}}\right), 81.1$ (s, $\left.\mathrm{CH}_{\text {cym }}\right), 78.9$ (s, $\left.\mathrm{CH}_{\text {cym }}\right), 60.1\left(\mathrm{~s}, \underline{\mathrm{CH}_{2}} \mathrm{CH}_{3}\right), 31.5$ (s, $\left.\underline{\mathrm{C}} \mathrm{HMe}_{2}\right), 22.4$ (s, $\left.\mathrm{CHMe}_{2}\right), 18.6$ (s, Me $\left.\mathrm{Mem}_{\mathrm{m}}\right), 14.5\left(\mathrm{~s}, \mathrm{CH}_{2} \underline{\mathrm{CH}}_{3}\right)$.

In situ generation of [( $\eta^{6}$-arene)RuH(NPN)] (2). General procedure. The hydride complexes $\mathbf{2}$ were generated in situ in a NMR tube. To a solution of the chloride complex $1(0.020$ $\mathrm{mmol})$ in $\mathrm{C}_{6} \mathrm{D}_{6}(0.6 \mathrm{~mL})$ and isopropanol $(0.20 \mathrm{mmol}, 10 \mu \mathrm{L})$, a NaHMDS solution ( $2.0 \mathrm{M}$ in THF, $15 \mu \mathrm{L}, 0.03 \mathrm{mmol}, 1.5$ equiv.) was added. The resulting suspension was vigorously stirred for $5 \mathrm{~min}$ at room temperature to complete the dissolution of $\mathbf{1}$ and then the reaction was followed by NMR.

Complex 2a was generated from $1 \mathrm{a}(0.014 \mathrm{~g}, 0.020 \mathrm{mmol})$ and NaHMDS $(0.030 \mathrm{mmol})$ in $95 \%$ after 2 h. ${ }^{31} \mathrm{P}\left\{{ }^{1} \mathrm{H}\right\}$ NMR $\left(\mathrm{C}_{6} \mathrm{D}_{6}\right): \delta$ 31.9. ${ }^{1} \mathrm{H}$ NMR $\left(\mathrm{C}_{6} \mathrm{D}_{6}\right): \delta 8.25\left(\mathrm{~m}, 2 \mathrm{H}, o-\mathrm{H}_{\mathrm{Ph}}\right), 7.43\left(\mathrm{~m}, 2 \mathrm{H}, o^{\prime}-\mathrm{H}_{\mathrm{Ph}}\right)$, $7.29\left(\mathrm{~m}, 3 \mathrm{H},(m+p)-\mathrm{H}_{\mathrm{Ph}}\right), 6.73\left(\mathrm{~m}, 3 \mathrm{H},(m+p)^{\prime}-\mathrm{H}_{\mathrm{Ph}}\right), 6.82\left(\mathrm{~d},{ }^{3} \mathrm{~J}_{\mathrm{HH}}=\right.$ 8.8, 4H, $\left.\mathrm{C}_{6} \mathrm{H}_{4}(\mathrm{Tol})\right), 6.79\left(\mathrm{~d},{ }^{3} \mathrm{~J}_{\mathrm{HH}}=9.2,4 \mathrm{H}, \mathrm{C}_{6} \mathrm{H}_{4}(\mathrm{Tol})\right), 2.07(\mathrm{~s}, 6 \mathrm{H}$, $\left.\mathrm{Me}_{\text {Tol }}\right), 1.95$ (s, $\left.18 \mathrm{H}, \mathrm{C}_{6} \mathrm{Me}_{6}\right),-3.30(\mathrm{RuH}) .{ }^{13} \mathrm{C}\left\{{ }^{1} \mathrm{H}\right\} \mathrm{NMR}\left(\mathrm{C}_{6} \mathrm{D}_{6}\right): \delta$ $147.5\left(\mathrm{~d},{ }^{2} J_{\mathrm{CP}}=3.8, i-\mathrm{C}_{\mathrm{Tol}}(\mathrm{N})\right), 138.8\left(\mathrm{~d},{ }^{1} J_{\mathrm{CP}}=101.3, i-\mathrm{C}_{\mathrm{Ph}}\right), 133.2$ $\left(d,{ }^{2} J_{\mathrm{CP}}=8.6, o^{\prime}-C_{\mathrm{Ph}}\right), 132.7\left(\mathrm{~d},{ }^{2} J_{\mathrm{CP}}=10.6, o-\mathrm{C}_{\mathrm{Ph}}\right), 131.6\left(\mathrm{~d},{ }^{4} J_{\mathrm{CP}}=\right.$ 2.7, $p$ - $\left.C_{P h}\right), 131.1\left(d,{ }^{4} J_{\mathrm{CP}}=2.6, p^{\prime}-C_{P h}\right), 130.5\left(d,{ }^{1} J_{\mathrm{CP}}=77.3, i^{\prime}-\right.$ $\left.C_{P h}\right), 128.8\left(s, m-C_{\text {Tol }}\right), 128.6\left(d,{ }^{3} J_{C P}=11.7, m-C_{P h}\right), 128.2\left(d, m^{\prime}-\right.$ $\left.C_{P h}\right), 127.0\left(d, 5 J_{C P}=2.3, p-C_{T o l}\right), 125.9\left(d,{ }^{3} J_{C P}=9.2, o-C_{T o l}\right), 90.1$ (s, $\left.\underline{\mathrm{C}}_{6} \mathrm{Me}_{6}\right), 20.7$ (s, Me $\left.\mathrm{Mol}_{\mathrm{To}}\right), 17.2$ (s, $\left.\mathrm{C}_{6} \underline{\mathrm{Me}}_{6}\right)$.

Analogously, from 1d (0.012 g, $0.019 \mathrm{mmol})$ and NaHMDS ( $0.028 \mathrm{mmol}$ ) complex $\mathbf{2 d}$ was generated in $65 \%$ yield after $1 \mathrm{~h}$. ${ }^{31} \mathrm{P}\left\{{ }^{1} \mathrm{H}\right\} \mathrm{NMR}\left(\mathrm{C}_{6} \mathrm{D}_{6}\right): \delta 41.3 .{ }^{1} \mathrm{H}$ NMR $\left(\mathrm{C}_{6} \mathrm{D}_{6}\right): \delta 7.98\left(\mathrm{~m}, 2 \mathrm{H}, \mathrm{o}-\mathrm{H}_{\mathrm{Ph}}\right)$, $7.59\left(\mathrm{~m}, 2 \mathrm{H}, o^{\prime}-\mathrm{H}_{\mathrm{Ph}}\right), 7.25$ (br. s, 3H, $\left.(m+p)-\mathrm{H}_{\mathrm{Ph}}\right), 6.92$ (br. s, $3 \mathrm{H}$, $\left.(m+p)^{\prime}-\mathrm{H}_{\mathrm{Ph}}\right), 6.83\left(\mathrm{~d},{ }^{3} \mathrm{~J}_{\mathrm{HH}}=8,2 \mathrm{H}, o-\mathrm{C}_{6} \mathrm{H}_{4}(\mathrm{Tol})\right), 6.78\left(\mathrm{~d},{ }^{3} \mathrm{~J}_{\mathrm{HH}}=7.6\right.$, $\left.2 \mathrm{H}, m-\mathrm{C}_{6} \mathrm{H}_{4}(\mathrm{Tol})\right), 2.52\left(\mathrm{~d}, 3^{3} \mathrm{HP}=20.4,3 \mathrm{H}, \mathrm{Me}(\mathrm{N})\right), 2.08(\mathrm{~s}, 3 \mathrm{H}$, $\left.\mathrm{Me}_{\text {Tol }}\right), 2.03$ (s, 18H, Me $\left.\mathrm{Cym}_{\mathrm{m}}\right),-3.72(\mathrm{~s}, 1 \mathrm{H}, \mathrm{RuH})$.

Analogously, from 1e (0.011 g, $0.014 \mathrm{mmol})$ and NaHMDS ( $0.014 \mathrm{mmol}$ ) complex $2 \mathrm{e}$ was generated in $92 \%$ yield after $2 \mathrm{~h}$. ${ }^{31} \mathrm{P}\left\{{ }^{1} \mathrm{H}\right\} \operatorname{NMR}\left(\mathrm{C}_{6} \mathrm{D}_{6}\right): \delta 38.4 .{ }^{1} \mathrm{H} \mathrm{NMR}\left(\mathrm{C}_{6} \mathrm{D}_{6}\right): \delta 8.09$ (ddd, ${ }^{3} \mathrm{JPP}_{\mathrm{HP}}=$ $\left.12.0,{ }^{3} J_{\mathrm{HH}}=8.0,{ }^{4} J_{\mathrm{HH}}=1.6,2 \mathrm{H}, o-\mathrm{H}_{\mathrm{Ph}}\right), 8.00\left(\mathrm{~d},{ }^{3} \mathrm{~J}_{\mathrm{HH}}=8.4,4 \mathrm{H}\right.$, $\left.\mathrm{C}_{6} \underline{\mathrm{H}}_{4}\left(\mathrm{CO}_{2} \mathrm{Et}\right)\right), 7.48\left(\mathrm{dd},{ }^{3} J_{\mathrm{HP}}=11.2,{ }^{3} J_{\mathrm{HH}}=7.6,2 \mathrm{H}, o^{\prime}-\mathrm{H}_{\mathrm{Ph}}\right), 7.24$ $\left(\mathrm{m}, 3 \mathrm{H},(m+p)-\mathrm{H}_{\mathrm{Ph}}\right), 6.82\left(\mathrm{t},{ }^{3} J_{\mathrm{HH}}=6.8,1 \mathrm{H}, p^{\prime}-\mathrm{H}_{\mathrm{Ph}}\right), 6.74\left(\mathrm{td},{ }^{3} \mathrm{~J}_{\mathrm{HH}}=\right.$ $\left.7.4,{ }^{4} J_{\mathrm{HP}}=2.4,2 \mathrm{H}, m^{\prime}-\mathrm{H}_{\mathrm{Ph}}\right), 6.67\left(\mathrm{~d},{ }^{3} J_{\mathrm{HH}}=8.4,4 \mathrm{H}, \mathrm{C}_{6} \mathrm{H}_{4}\left(\mathrm{CO}_{2} \mathrm{Et}\right)\right)$, $4.81\left(\mathrm{~d}, 3 \mathrm{~J}_{\mathrm{HH}}=5.6,2 \mathrm{H}, \mathrm{C}_{6} \mathrm{H}_{4}(\mathrm{Cym})\right), 4.74\left(\mathrm{~d}, 3 \mathrm{~J}_{\mathrm{HH}}=6.0,2 \mathrm{H}\right.$, $\left.\mathrm{C}_{6} \mathrm{H}_{4}(\mathrm{Cym})\right), 4.13\left(\mathrm{q},{ }^{3} J_{\mathrm{HH}}=6.6,4 \mathrm{H}, \mathrm{C}_{2} \mathrm{CH}_{3}\right), 2.54$ (sept, ${ }^{3} J_{\mathrm{HH}}=$ 6.8, $\left.1 \mathrm{H}, \mathrm{CHMe}_{2}\right), 1.88\left(\mathrm{~s}, 3 \mathrm{H}, \mathrm{Me}_{\text {cym }}\right), 1.23\left(\mathrm{~d}, 3^{3} \mathrm{HH}=6.8,6 \mathrm{H}\right.$, $\left.\mathrm{CHMe}_{2}\right), 1.01\left(\mathrm{t},{ }^{3} \mathrm{~J}_{\mathrm{HH}}=6.6,6 \mathrm{H}, \mathrm{CH}_{2} \underline{\mathrm{CH}}_{3}\right),-2.98(\mathrm{~s}, 1 \mathrm{H}, \mathrm{RuH})$. ${ }^{13} \mathrm{C}\left\{{ }^{1} \mathrm{H}\right\} \operatorname{NMR}\left(\mathrm{C}_{6} \mathrm{D}_{6}\right): \delta 166.7$ (s, $\left.\underline{\mathrm{CO}}_{2} \mathrm{Et}\right), 156.0\left(\mathrm{~d},{ }^{2} J_{\mathrm{CP}}=6.3, i-\right.$ $\left.\mathrm{C}_{\mathrm{N}}\left(\mathrm{CO}_{2} \mathrm{Et}\right)\right), 132.8\left(\mathrm{~d},{ }^{2} J_{\mathrm{CP}}=10.0, o-\mathrm{C}_{\mathrm{Ph}}\right), 132.6\left(\mathrm{~d},{ }^{4} J_{\mathrm{CP}}=3.0, p-\right.$ $\left.C_{P h}\right), 132.5\left(d,{ }^{1} J_{C P}=94.6, i-C_{P h}\right), 132.5\left(d,{ }^{4} J_{C P}=2.5, p^{\prime}-C_{P h}\right), 132.4$ $\left(d,{ }^{2} J_{\mathrm{CP}}=10.8, o^{\prime}-\mathrm{C}_{\mathrm{Ph}}\right), 130.6\left(\mathrm{~s}, m-\mathrm{C}_{6} \mathrm{H}_{4}\left(\mathrm{CO}_{2} \mathrm{Et}\right)\right), 129.3\left(\mathrm{~d},{ }^{3} J_{\mathrm{CP}}=\right.$ $\left.11.9, m-C_{P h}\right), 127.9\left(d,{ }^{1} J_{\mathrm{CP}}=103.5, i^{\prime}-C_{\mathrm{Ph}}\right), 128.8\left(\mathrm{~d},{ }^{3} J_{\mathrm{CP}}=11.8\right.$, $\left.m^{\prime}-\mathrm{C}_{\mathrm{Ph}}\right), 121.9\left(\mathrm{~d},{ }^{3} \mathrm{~J}_{\mathrm{CP}}=12.3, o-\mathrm{C}_{6} \mathrm{H}_{4}\left(\mathrm{CO}_{2} \mathrm{Et}\right)\right), 119.6(\mathrm{~s}, p-$ $\left.\mathrm{C}_{6} \mathrm{H}_{4}\left(\mathrm{CO}_{2} \mathrm{Et}\right)\right), 107.2\left(\mathrm{~s}, i-\mathrm{C}_{\mathrm{Cym}}\right), 101.1\left(\mathrm{~s}, i^{\prime}-\mathrm{C}_{\mathrm{cym}}\right), 81.2\left(\mathrm{~s}, \mathrm{CH}_{\mathrm{cym}}\right)$, 76.1 (s, $\left.\mathrm{CH}_{\mathrm{cym}}\right), 60.0$ (s, $\left.\underline{\mathrm{C}_{2}} \mathrm{CH}_{3}\right), 32.7$ (s, $\left.\underline{\mathrm{C}} \mathrm{HMe}_{2}\right), 23.9$ (s, $\left.\mathrm{CHMe}_{2}\right), 19.8$ (s, Me $\left.\mathrm{M}_{\mathrm{ym}}\right), 14.5$ (s, $\left.\mathrm{CH}_{2} \mathrm{CH}_{3}\right)$.

Alternative method of generation of $\mathbf{2 c}$. To a solution of $\mathbf{1 c}$ $(0.011 \mathrm{~g}, 0.020 \mathrm{mmol})$ in $\mathrm{C}_{6} \mathrm{D}_{6}(0.6 \mathrm{~mL}), \mathrm{NaEt}_{3} \mathrm{BH}(1.0 \mathrm{M}$ in toluene, $20 \mu \mathrm{L}, 0.020 \mathrm{mmol}$ ) was added, the resulting mixture was shaken for $5 \mathrm{~min}$ at room temperature and analyzed by ${ }^{31} \mathrm{P}\left\{{ }^{1} \mathrm{H}\right\} \mathrm{NMR}$. According to ${ }^{31} \mathrm{P}\left\{{ }^{1} \mathrm{H}\right\} \mathrm{NMR}\left(\mathrm{C}_{6} \mathrm{D}_{6}\right)$, the content of $2 \mathrm{c}$ $\left(\delta_{\mathrm{P}} 49.8, \delta_{\mathrm{RuH}}-4.12\right)$ after $20 \mathrm{~min}$ was ca. $70 \%$ and it gradually decreased with time.

Catalytic studies. In a typical experiment, the precatalyst 1 (0.02 mmol) was suspended in $i \operatorname{PrOH}(5 \mathrm{~mL})$ and then treated (if appropriate) with a $0.6 \mathrm{M}$ solution of NaHMDS in toluene (1-1.5 equiv.). In the presence of base, the mixture was preliminary stirred for 5-120 minutes (Table 1), then it was warmed at the desired temperature followed by the addition of dodecane ( 1 $\mathrm{mmol}, 0.225 \mathrm{ml}$ ) and acetophenone $(2 \mathrm{mmol}, 0.233 \mathrm{ml})$. Aliquots $(0.1 \mathrm{~mL})$ were diluted with diethyl ether $(0.8 \mathrm{~mL})$ and filtered through a silica bed. The reaction samples were analysed by GC equipped with J\&W GC Column with a DB-1MS stationary phase (program: $25 \mathrm{~min}$ at $50^{\circ} \mathrm{C}$, with further heating rate $20^{\circ} \mathrm{C} / \mathrm{min}$ to $170{ }^{\circ} \mathrm{C}$; retention times: $\tau$ (acetophenone) $=$ $24 \mathrm{~min}, \tau(1$-phenylethanol $)=25 \mathrm{~min}, \tau($ dodecane $)=31 \mathrm{~min})$.

$\mathbf{X}$-ray crystallography. Single crystals of $\mathbf{1 d}$, $\mathbf{1 e}$ were obtained by slow diffusion of hexane into benzene solutions. The data collections were performed on a Bruker APEX DUO diffractometer equipped with an Apex II CCD detector, using CoK $\alpha$ radiation $(\lambda=1.54178 \AA$ ) for 1 e and MoK $\alpha$ radiation $(\lambda=$ $0.71073 \AA$ ) for $1 \mathbf{d}$. Frames were integrated using the Bruker SAINT software package ${ }^{32}$ by a narrow-frame algorithm. A semiempirical absorption correction was applied with the TWINABS (1e) or the SADABS ${ }^{33}$ (1d) programs using the intensity data of equivalent reflections. The structures were solved with the dual-space method with SHELXT ${ }^{34}$ and refined by the full-matrix least-squares technique against $F^{2}{ }_{h k l}$ in anisotropic approximation with the SHELXL ${ }^{35}$ software package. The positions of the hydrogen atoms were calculated, and all hydrogen atoms were refined using the riding model with $1.5 \mathrm{Ueq}(\mathrm{Cm})$ and $1.2 \mathrm{Ueq}(\mathrm{Ci})$, where $\mathrm{Ueq}(\mathrm{Cm})$ and $1.2 \mathrm{Ueq}(\mathrm{Ci})$ are respectively the equivalent thermal parameters of methyl and all other carbon atoms to which corresponding $\mathrm{H}$ atoms are bonded. The crystals of 1 e were twins of relatively poor quality; the maximal achieved data completeness was only $83.2 \%$ up to the resolution of $0.833 \AA$. However, due to the high data/parameters ratio $(>10)$ and relatively low residuals we do 
not have doubts about the correctness of this crystal structure. Detailed crystallographic information is given in Table S3. Crystallographic data have been deposited to the Cambridge Crystallographic Data Centre, CCDC numbers 19568271956828. Copies of the data can be obtained free of charge via http://www.ccdc.cam.ac.uk/data_request/cif, or by e-mailing data_request@ccdc.cam.ac.uk, or by contacting The Cambridge Crystallographic Data Centre, 12 Union Road, Cambridge CB2 1EZ, UK; fax: +44(0)1223-336033.

Computational Details. The calculations were carried out using the Gaussian 09 program package ${ }^{36}$ within the DFT approach using the 97D functional, ${ }^{37}$ which implicitly includes a dispersion correction. The basis set comprised the LANL2DZ basis set, which includes an ECP and augmented with an $f$ polarization function $(\alpha=1.235)^{38}$ for the Ru atom, and the standard 6$311 \mathrm{G}(\mathrm{d}, \mathrm{p})^{39}$ basis sets for all other atoms. The solvation effect was included during optimization by use of the SMD polarisable continuum in isopropanol $(\varepsilon=19,264)$. Thermochemical corrections were obtained at $298.15 \mathrm{~K}$ on the basis of frequency calculations, using the standard approximations (ideal gas, rigid rotor and harmonic oscillator). A further correction of 1.95 $\mathrm{Kcal} / \mathrm{mol}$ was applied to bring the $\mathrm{G}$ values from the gas phase $(1 \mathrm{~atm})$ to the solution $(1 \mathrm{~mol} / \mathrm{L})$ standard state. ${ }^{40}$

\section{Conclusions}

With this study we have demonstrated the effect of the N,Psubstituents in the NPN ligand and the arene nature on the performance of the (Arene)Ru(NPN) complexes in acetophenone transfer hydrogenation catalysis. We have discovered that the $\mathrm{N}$-atoms basicity is the feature that defines both the mechanism of the outer-sphere hydrogen transfer to ketone, either involving NPN ligand-assistance or without this precoordination step, and the conditions at which the catalyst can operate.

Under basic conditions, when the precatalyst is converted into the active ruthenium hydride species, the less sterically encumbering $p$-cymene ligand and the more electron-donating $\mathrm{N}$-substituents favour the catalyst activity, although both decrease the stability of the catalytically active hydride species, due to either side rearrangement to $16 \bar{e} \eta^{5}$-cyclohexadienyl complexes ${ }^{25}$ or facile protonation of the $\mathrm{N}$-atoms following by the NPN ligand decoordination, respectively. Replacement of the P-phenyl groups with ethyl substituents has little effect on the catalyst performance, while its stability suffers significantly because of the NPN ligand degradation due to concurrent P-N bond breaking with alkoxide-ion. In general, preliminary generation of the active RuH species strongly limits the overall stability of the catalytic system making it very sensitive to the quality of the solvent and the temperature.

The use of base is not necessary for the complexes with basic N-Me groups, which is a rare occurrence in transfer hydrogenation catalysis; without base these precatalysts are also highly active and significantly more stable. With the help of kinetic analyses and DFT calculations we have suggested an alternative mechanism of transfer hydrogenation under basefree conditions, which involves assistance of the basic $\mathrm{N}$-atom for precoordination of the ketone to form a pericyclic transition state similarly to the proposed one for Noyori-lkariya catalysts. From the practical point of view, the major advantage of using $\mathrm{N}$-methylated RuNPN catalysts under base-free conditions is the long-term [(Arene)Ru(NPN)] ${ }^{+}$stability to protonolysis with isopropanol, which seems to be the catalyst main degradation pathway, especially at elevated temperatures.

\section{Conflicts of interest}

There are no conflicts to declare.

\section{Acknowledgements}

This work was supported by Russian Science Foundation (grant No. 19-13-00459). Spectral characterization, elemental analysis were performed with the financial support from Ministry of Science and Higher Education of the Russian Federation using the equipment of Center for molecular composition studies of INEOS RAS. We also thank the French "Ministère des Affaires Etrangères" for a Ph.D. fellowship to ISS and the CALMIP mesocenter of the University of Toulouse for a grant of computational time.

\section{Notes and references}

1 Topics in Organometallic Chemistry: Bifunctional Molecular Catalysis, T. Ikariya and M. E. Shibasaki, (Eds.), Springer: Berlin, 2011, vol. 37.

2 D. Wang and D. Astruc, Chem. Rev., 2015, 115, 6621-6686.

3 X. Wu, C. Wang and J. Xiao, Platin. Met. Rev., 2010, 54, 3-19.

4 S. Hashiguchi, A. Fujii, J. Takehara, T. Ikariya and R. Noyori, J. Am. Chem. Soc., 1995, 117, 7562-7563.

5 J. Takehara, S. Hashiguchi, A. Fujii, S.-i. Inoue, T. Ikariya and R. Noyori, Chem. Commun., 1996, 233-234.

6 K. Murata and T. Ikariya, J. Org. Chem., 1999, 64, 2186-2187.

7 T. Ikariya and A. J. Blacker, Accounts Chem. Res., 2007, 40, 1300-1308.

8 I. Masato, S. Yuji, W. Akira and I. Takao, Synlett, 2009, 10, 1621-1626.

9 T. Touge, T. Hakamata, H. Nara, T. Kobayashi, N. Sayo, T. Saito, Y. Kayaki and T. Ikariya, J. Am. Chem. Soc., 2011, 133, 1496014963.

10 P. A. Dub, A. Matsunami, S. Kuwata and Y. Kayaki, J. Am. Chem. Soc., 2019, 141, 2661-2677.

11 R. Hodgkinson, V. Jurcik, A. Zanotti-Gerosa, H.G. Nedden, A. Blackaby, G.J. Clarkson and M. Wills, Organometallics, 2014, 33, 5517-5524.

12 R. Noyori and S. Hashiguchi, Accounts Chem. Res., 1997, 30, 97-102.

13 M. J. Palmer and M. Wills, Tetrahedron-Asymmetr, 1999, 10, 2045-2061.

14 M. Yamakawa, H. Ito and R. Noyori, J. Am. Chem. Soc., 2000, 122, 1466-1478.

15 C. P. Casey and J. B. Johnson, J. Org. Chem., 2003, 68, 19982001.

16 T. Koike and T. Ikariya, Adv. Synth. Catal., 2004, 346, 37-41.

17 J. S. M. Samec, J. E. Backvall, P. G. Andersson and P. Brandt, Chem. Soc. Rev., 2006, 35, 237-248.

18 L. J. Hounjet, M. J. Ferguson and M. Cowie, Organometallics, 2011, 30, 4108-4114. 
19 W. W. N. O, A. J. Lough and R. H. Morris, Organometallics, 2011, 30, 1236-1252.

20 P. A. Dub and T. Ikariya, J. Am. Chem. Soc., 2013, 135, 26042619.

21 P. A. Dub and J. C. Gordon, Dalton Trans., 2016, 45, 67566781.

22 P. A. Dub and J. C. Gordon, ACS Catalysis, 2017, 7, 6635-6655.

23 J.-W. Handgraaf and E. J. Meijer, J. Am. Chem. Soc., 2007, 129, 3099-3103

24 A. Pavlova and E. J. Meijer, ChemPhysChem, 2012, 13, 3492 3496.

25 I. S. Sinopalnikova, T. A. Peganova, N. V. Belkova, E. Deydier, J. C. Daran, E. S. Shubina, A. M. Kalsin and R. Poli, Eur. J. Inorg. Chem., 2018, 2018, 2285-2299.

26 I. S. Sinopalnikova, T. A. Peganova, V. V. Novikov, I. V. Fedyanin, O. A. Filippov, N. V. Belkova, E. S. Shubina, R. Poli and A. M. Kalsin, Chem. Eur. J., 2017, 23, 15424-15435.

27 T. A. Peganova, I. S. Sinopalnikova, A. S. Peregudov, I. V. Fedyanin, A. Demonceau, N. A. Ustynyuk and A. M. Kalsin, Dalton Trans., 2016, 45, 17030-17041.

28 O. V. Gusev, T. A. Peganova, A. V. Gonchar, P. V. Petrovskii, K. A. Lyssenko and N. A. Ustynyuk, Phosphorus Sulfur, 2009, 184, 322-331.

29 T. A. Peganova and A. M. Kalsin, Synthesis, accepted. DOI: 10.1055/s-0039-1690242.

30 M. Bennett, T. N. Huang, T. Matheson, A. Smith, S. Ittel and W. Nickerson, Inorg. Syn., 1982, 21, 74-78.

31 S. B. Jensen, S. J. Rodger and M. D. Spicer, J. Organomet. Chem., 1998, 556, 151-158.

32 SAINT v8.34A., Bruker AXS, Madison, Wisconsin, USA, 2013.

33 L. Krause, R. Herbst-Irmer, G. M. Sheldrick and D. Stalke, J. Appl. Crystallogr., 2015, 48, 3-10.

34 G. Sheldrick, Acta Crystallogr. A, 2015, 71, 3-8.

35 G. M. Sheldrick, Acta Crystallogr. C, 2015, C71, 3-8.

36 M. J. Frisch, G. W. Trucks, H. B. Schlegel, G. E. Scuseria, M. A. Robb, J. R. Cheeseman, G. Scalmani, V. Barone, B. Mennucci, G. A. Petersson, H. Nakatsuji, M. Caricato, X. Li, H. P. Hratchian, A. F. Izmaylov, J. Bloino, G. Zheng, J. L. Sonnenberg, M. Hada, M. Ehara, K. Toyota, R. Fukuda, J. Hasegawa, M. Ishida, T. Nakajima, Y. Honda, O. Kitao, H. Nakai, T. Vreven, J. J. A. Montgomery, J. E. Peralta, F. Ogliaro, M. Bearpark, J. J. Heyd, E. Brothers, K. N. Kudin, V. N. Staroverov, R. Kobayashi, J. Normand, K. Raghavachari, A. Rendell, J. C. Burant, S. S. lyengar, J. Tomasi, M. Cossi, N. Rega, J. M. Millam, M. Klene, J. E. Knox, J. B. Cross, V. Bakken, C. Adamo, J. Jaramillo, R. Gomperts, R. E. Stratmann, O. Yazyev, A. J. Austin, R. Cammi, C. Pomelli, J. W. Ochterski, R. L. Martin, K. Morokuma, V. G. Zakrzewski, G. A. Voth, P. Salvador, J. J. Dannenberg, S. Dapprich, A. D. Daniels, Ö. Farkas, J. B. Foresman, J. V. Ortiz, J. Cioslowski and D. J. Fox, Gaussian 09 (Gaussian, Inc. Wallingford CT, 2009).

37 S. Grimme, J. Comp. Chem, 2006, 27, 1787-1799.

38 A. W. Ehlers, M. Boehme, S. Dapprich, A. Gobbi, A. Hoellwarth, V. Jonas, K. F. Koehler, R. Stegmann, A. Veldkamp and G. Frenking, Chem. Phys. Lett., 1993, 208, 111-114.

39 R. Krishnan, J. S. Binkley, R. Seeger and J. A. Pople, J. Chern. Phys., 1980, 72, 650-654

40 V. S. Bryantsev, M. S. Diallo and W. A. Goddard, III, J. Phys. Chem. B, 2008, 112, 9709-9719. 